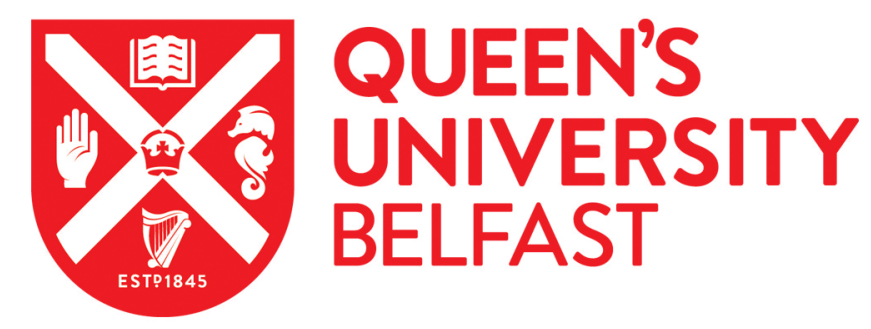

\title{
Hydration and properties of sodium sulfate activated slag
}

Rashad, A. M., Bai, Y., Basheer, P. A. M., Milestone, N. B., \& Collier, N. C. (2013). Hydration and properties of sodium sulfate activated slag. Cement and Concrete Composites, 37(1), $20-29$.

https://doi.org/10.1016/j.cemconcomp.2012.12.010

Published in:

Cement and Concrete Composites

Document Version:

Peer reviewed version

Queen's University Belfast - Research Portal:

Link to publication record in Queen's University Belfast Research Portal

\section{Publisher rights}

This is the author's version of a work that was accepted for publication in Cement and Concrete Composites. Changes resulting from the publishing process, such as peer review, editing, corrections, structural formatting, and other quality control mechanisms may not be reflected in this document. Changes may have been made to this work since it was submitted for publication. A definitive version was subsequently published in Cement and Concrete Composites, [VOL 37, (2013)]

\section{General rights}

Copyright for the publications made accessible via the Queen's University Belfast Research Portal is retained by the author(s) and / or other copyright owners and it is a condition of accessing these publications that users recognise and abide by the legal requirements associated with these rights.

\section{Take down policy}

The Research Portal is Queen's institutional repository that provides access to Queen's research output. Every effort has been made to ensure that content in the Research Portal does not infringe any person's rights, or applicable UK laws. If you discover content in the Research Portal that you believe breaches copyright or violates any law, please contact openaccess@qub.ac.uk. 


\section{Accepted Manuscript}

Hydration and properties of sodium sulfate activated slag

A.M. Rashad, Y. Bai, P.A.M. Basheer, N.B. Milestone, N.C. Collier

PII:

S0958-9465(12)00246-6

DOI:

http://dx.doi.org/10.1016/j.cemconcomp.2012.12.010

Reference:

CECO 2145

To appear in:

Cement \& Concrete Composites

Cement \&

Concrete

\section{Composites}

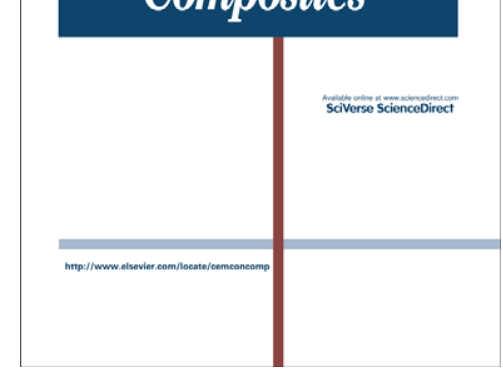

Received Date:

Revised Date:

Accepted Date:
3 May 2011

16 December 2012

18 December 2012

Please cite this article as: Rashad, A.M., Bai, Y., Basheer, P.A.M., Milestone, N.B., Collier, N.C., Hydration and properties of sodium sulfate activated slag, Cement \& Concrete Composites (2012), doi: http://dx.doi.org/10.1016/ j.cemconcomp.2012.12.010

This is a PDF file of an unedited manuscript that has been accepted for publication. As a service to our customers we are providing this early version of the manuscript. The manuscript will undergo copyediting, typesetting, and review of the resulting proof before it is published in its final form. Please note that during the production process errors may be discovered which could affect the content, and all legal disclaimers that apply to the journal pertain. 


\title{
Hydration and properties of sodium sulfate activated slag
}

A. M. Rashad ${ }^{\mathrm{a} *}$ Y. Bai ${ }^{\text {b* }}$, P. A. M. Basheer ${ }^{\text {c }}$, N. B. Milestone ${ }^{\mathrm{d}}$ and N. C. Collier ${ }^{\mathrm{d}}$

${ }^{a}$ Building Materials Research and Quality Control Institute, Housing \& Building National Research Center, HBRC, 87 El-Tahrir St., Dokki, Giza 11511, P.O. Box: 1770 Cairo, Egypt

${ }^{\mathrm{b}}$ Department of Civil, Environmental \& Geomatic Engineering, University College London, Chadwick Building, Gower Street, London WC1E 6BT, UK

c School of Planning, Architecture \& Civil Engineering, Queen's University Belfast, David Keir Building, Stranmillis Road, Belfast BT9 5AG, UK

d Immobilisation Science Laboratory, Department of Engineering Materials, Formerly at the University of Sheffield, Mappin Street, Sheffield S1 3JD, UK

\begin{abstract}
Interest in alkali-activated slag as a construction material is increasing, primarily due to its environmentally friendly nature. Although strong alkaline activators, such as sodium hydroxide and sodium silicate solution, are preferred for high strength, none of them exists naturally and their manufacturing process is quite energy intensive. Whilst sodium sulfate $\left(\mathrm{Na}_{2} \mathrm{SO}_{4}\right)$ can be obtained from natural resources, the early strength of $\mathrm{Na}_{2} \mathrm{SO}_{4}$ activated slag is usually low. In this paper, the effects of slag fineness and $\mathrm{Na}_{2} \mathrm{SO}_{4}$ dosage on strength, $\mathrm{pH}$, hydration and microstructure were investigated and compared with those of a pure Portland cement (PC). Test results indicated that increasing the slag

* Corresponding Author: Mobile: (+2)01228527302, Fax: (+202)33351564, (+202)33367179 E-Mail: alaarashad@yahoo.com (Alaa. M. Rashad); yun.bai@ucl.ac.uk (Y. Bai): previously School of Planning, Architecture \& Civil Engineering, Queen's University Belfast.
\end{abstract}


fineness is a more effective approach than increasing $\mathrm{Na}_{2} \mathrm{SO}_{4}$ dosage for increasing both the early and long-term strength of $\mathrm{Na}_{2} \mathrm{SO}_{4}$ activated slags. In addition, increasing the slag fineness can also increase the strength without increasing the $\mathrm{pH}$ of the hardened matrix, which is beneficial for immobilizing certain types of nuclear waste containing reactive metals and resins.

Keywords: Alkali-activator, fineness, $\mathrm{pH}$, hydration, sodium sulfate, slag.

\section{1- Introduction}

The construction activities in many countries around the world demand large volumes of cement production. This consumes huge amounts of energy, in particular, arising from the calcination of raw materials at around $1500{ }^{\circ} \mathrm{C}$ and the grinding of raw materials, cement clinker and gypsum [1]. The energy demand associated with Portland cement (PC) production is about 1700-1800 MJ/tonne clinker [2], which is the third largest use of energy, after that of the aluminium and steel manufacturing industries [3]. In addition, nearly 0.85 tonnes of $\mathrm{CO}_{2}$ are released to the atmosphere per tonne of PC clinker produced. The world cement production accounts for approximately $7 \%$ of the 23000 million tonnes of $\mathrm{CO}_{2}$ produced annually by human activities [4]. 
In recent years, researchers have been trying to use different types of by-products, such as pulverized fuel ash (PFA) and ground granulated blast-furnace slag (hereafter referred to as slag), as partial replacements of $\mathrm{PC}$ in order to reduce the energy consumption and $\mathrm{CO}_{2}$ emission associated with the concrete industry. However, despite this use, the vast majority of slag is still disposed of in landfills $[5,6]$ due to the reduction of early age compressive strength when PC is replaced with slag.

Instead of partially replacing PC with these industrial by-products, thereby indirectly activating the by-products by calcium hydroxide generated by PC hydration along with the alkalis and gypsum in PC, the by-products like PFA and slag can also be directly activated with chemical activators. Much attention has been given to alkali-activated slag (AAS) systems [6-17], including their mechanisms of hydration, hydration products, the microstructure and activators [18-24]. It has generally been agreed that the strength development of AAS depends on the type and dosage of alkali activator, fineness of the slag and the temperature of curing [25-26]. Wang et al. [21] found that the optimum amount of activator dosage, in terms of $\mathrm{Na}_{2} \mathrm{O}$ by the mass of slag, varies from $3 \%$ to $5.5 \%$ and using waterglass with a silica modulus of 1-1.5 leads to higher mechanical strengths. Compressive strengths of 60 and $150 \mathrm{MPa}$ for slag concretes activated by waterglass were achieved 
without heat treatment or special additives [27, 28]. They also found that using powdered waterglass leads to lower strength when compared to the liquid form. Fernández-Jiménez et al. [29] also reported that the optimum concentration of the alkaline activator varies between $3 \%$ and $5 \%$ of $\mathrm{Na}_{2} \mathrm{O}$ by slag mass and using a $\mathrm{Na}_{2} \mathrm{O}$ amount above these limits would result in cost inefficient mixtures as well as problems with efflorescence. As a function of the strength obtained, the alkali activators used in their work maintained the following sequence: $\mathrm{Na}_{2} \mathrm{SiO}_{3} \cdot \mathrm{nH}_{2} \mathrm{O}+\mathrm{NaOH}>>$ $\mathrm{Na}_{2} \mathrm{CO}_{3}>\mathrm{NaOH}$. Similar findings were reported by Bakharev et al. [30] and Atiş et al. [31]. Krizan and Zivanovic [32] studied the early hydration of alkali-slag cements activated with waterglass at different $n$ moduli $(0.6,0.9,1.2$ and 1.5$)$ and sodium metasilicate $\left(\mathrm{Na}_{2} \mathrm{SiO}_{3} .5 \mathrm{H}_{2} \mathrm{O}\right)$ in solution at $25{ }^{\circ} \mathrm{C}$ using isothermal conduction calorimetry. The results indicated that the cumulative heat of hydration increased with increasing modulus and dosage of waterglass. Furthermore, the compressive strength of the slag activated with waterglass of higher moduli (up to 1.5) gave higher strengths.

From the above review of the literature, it can be seen that, whilst the most commonly used activators are sodium silicate, sodium hydroxide, sodium carbonate or a mixture of sodium - potassium hydroxide $(\mathrm{NaOH}, \mathrm{KOH})$ with sodium silicate (waterglass) - potassium 
silicate, the mixture of sodium hydroxide with waterglass has been generally agreed to be the most effective activator and provides the best formulation for high strength and other advantageous properties. However, both the sodium hydroxide and sodium silicate do not exist naturally and they are obtained from energy intensive manufacturing processes. This is particularly the case for sodium silicate, which is produced by melting sand and sodium carbonate at $1350-1450{ }^{\circ} \mathrm{C}$, followed by dissolving in an autoclave at $140-160{ }^{\circ} \mathrm{C}$ under suitable steam pressure [33]. As a result, even though AAS could potentially be considered as a low energy and low carbon cement system, activation with sodium silicate and sodium hydroxide may not be the best option for achieving environmentally friendly cementitious systems. As highlighted by Habert et al. [34], the objective of using alkali-activated cementitious systems is to reduce the negative effects of construction on the environment, which at present is not achieved with the use of both sodium silicate and sodium hydroxide.

Unlike sodium silicate and sodium hydroxide, sodium sulfate $\left(\mathrm{Na}_{2} \mathrm{SO}_{4}\right)$ can be obtained either from natural occurring sodium-sulfatebearing brines, crystalline evaporate deposits or as a by-product during the manufacture of various products such as viscose rayon, hydrochloric acid and silica pigments. Thus, by using sodium sulfate as an activator a 
more environmentally friendly cementitious system could be formulated. Furthermore, compared to other alkaline activators, sodium sulfate is usually less expensive and less harmful. However, surprisingly, compared to other activators, there have been very limited studies addressing the activation of slag with sodium sulfate. One possible reason for its low popularity could be due to its low early strength. As reported by Wang et al. [21] the early compressive strength of AAS mortars activated with sodium sulfate is lower than other activators such as $\mathrm{Na}_{2} \mathrm{CO}_{3}, \mathrm{NaOH}$ and waterglass. The recorded compressive strengths of the mortars activated with $2 \mathrm{M} \mathrm{Na}_{2} \mathrm{SO}_{4}$ were $1.2,5.1,10.2$ and $20 \mathrm{MPa}$ at the ages of $1,3,7$ and 28 days, respectively. These results of compressive strength were lower than those obtained from other activators, in particular the early age strength. However, recent work carried out by Rashad et al. [35] indicated that $\mathrm{Na}_{2} \mathrm{SO}_{4}$ activated slag has a better resistance than PC systems to the degradation caused by exposure to elevated temperature up to $600{ }^{\circ} \mathrm{C}$ [35]. Sodium sulfate activated slag has also been considered as a potential binder for dealing with some nuclear wastes containing reactive metals due to its reduced $\mathrm{pH}$, reduced heat generated from hydration compared to PC-based blends and less free water content due to the formation of ettringite $[35,36]$. Nonetheless, to satisfy the requirements of the construction industry, its low early strength must be addressed. Although, 
by adding alkaline additives, such as lime and PC clinker, the early strength of $\mathrm{Na}_{2} \mathrm{SO}_{4}$ activated slag could be improved [21], it may again increase the embodied energy consumption and $\mathrm{CO}_{2}$ emission. On the other hand, the addition of alkaline additives would increase the $\mathrm{pH}$ of the activated slag. Although the increased $\mathrm{pH}$ would be preferred for construction industry due to the enhanced stability of the reinforcing steel, it may cause concerns in some nuclear waste immobilization applications, as the increased $\mathrm{pH}$ could lead to the reactions between activated slag with certain metallic wastes, such as aluminium, causing expansive corrosion of metals and excessive generation of hydrogen, along with attacks on zeolites and glass which may exist in certain waste forms [37].

It is well-established that by increasing the fineness of the materials, the reactivity can be enhanced due to the increased surface area and surface energy. Therefore, the primary objective of this study was to investigate the effect of the fineness of slag and the dosage of sodium sulfate on the hydration, $\mathrm{pH}$ and compressive strength of sodium sulfate activated slag in an attempt to increase its early-age strength without increasing the $\mathrm{pH}$. In addition, it is expected that an improved understanding on the hydration mechanism of sodium sulfate activated slag system could be achieved. 


\section{Experimental}

\subsection{Materials}

Industrial grade of $\mathrm{Na}_{2} \mathrm{SO}_{4}$ was used as an activator. The slag supplied by UK Hanson Cement was used as the raw material to produce the activated slag paste. Its chemical composition was characterised by X-ray fluorescence (XRF) spectrometry. Two degrees of slag fineness with specific surface areas of, 2500 and $5000 \mathrm{~cm}^{2} / \mathrm{g}$ were used. Portland cement, CEMI Class 42.5R, with a Blaine surface area of $2700 \mathrm{~cm}^{2} / \mathrm{g}$ (complies with BS EN 197-1: 2001), was used as a reference. The corresponding oxide contents of the slag and PC, calculated from elemental compositions determined by XRF, are shown in Table 1.

\subsection{Mixture proportions}

Four activated slag pastes and a control PC paste were prepared. The activated slag pastes were formulated with two different dosages of sodium sulfate $\left(1\right.$ and $3 \% \mathrm{Na}_{2} \mathrm{O}$ equivalent of $\mathrm{Na}_{2} \mathrm{SO}_{4}$ by the mass of slag) and the slag with two different finenesses. All mixing proportions are detailed in Table 2. A water binder ratio (w/b) of 0.3 was fixed for all mixtures. 


\subsection{Method}

The slag was dried for $6 \mathrm{~h}$ in a special dryer at $40 \pm 1{ }^{\circ} \mathrm{C}$ before mixing. The sodium sulfate solution was prepared and used at $40 \pm 1{ }^{\circ} \mathrm{C}$. The slag was added to the sodium sulfate solution that has been previously placed in the bowl of a Hobart planetary mixer, over a 5 min period after which time the mixer was stopped and any unmixed powders was scraped from the sides and the paddle into the mixing bowl. Mixing was then continued for $5 \mathrm{~min}$ before casting into $25 \times 25 \times 25 \mathrm{~mm}$ moulds and vibrating for $1 \mathrm{~min}$ to remove air bubbles. The same mixing regime was used for the PC paste. Immediately after casting, the moulds were covered with wet hessian and sealed in plastic sample bags. All specimens were then cured in an oven at $40 \pm 1{ }^{\circ} \mathrm{C}$. At the end of three days, the specimens were removed from the steel moulds. The 3-day compressive strength was tested immediately after demoulding. The remaining specimens were again wrapped with a wet hessian, sealed in a plastic sample bag and stored in the oven at $40 \pm 1{ }^{\circ} \mathrm{C}$ up to 91 days. The hessian was checked at regular intervals to ensure that sufficient moisture was supplied for the ongoing hydration of the specimens.

The paste workability was measured immediately after mixing using a mini-slump test. In this test, a small cone, with a bottom diameter of $38.1 \mathrm{~mm}$, a top diameter of $19 \mathrm{~mm}$ and a height of $52.7 \mathrm{~mm}$ was 
placed at the centre of a square piece of smooth plastic, and the test was carried out by following the standard procedure [38].

The compressive strength of samples hydrated for 3, 7, 28, 56 and 91 days was measured in triplicate in accordance with BS EN 1961:2005(E). A universal compressive strength testing machine with a constant load rate of $50 \mathrm{kN} / \mathrm{min}$ and $100 \mathrm{kN}$ capacity was used to measure the compressive strength of the $25 \times 25 \times 25 \mathrm{~mm}$ cubes. After compressive strength testing, the debris from the crushed specimens were stored in acetone in order to stop their hydration. After being stored in the acetone for three days, the debris were filtered from the acetone and then dried in a desiccator under vacuum. Part of the dried samples was ground in an agate mortar. Particles passing a $63 \mu \mathrm{m}$ sieve were used for X-ray diffraction (XRD) and thermogravimetric (TGA) analyses. Selected pieces were also used for the scanning electron microscopy (SEM) analysis.

The heat of the hydration of sodium sulfate activated slag was measured using a TAM air calorimeter. Immediately before the test, 50 gram of slag was mixed with the sodium sulfate solution by hand for a fixed length of time. About 5 gram of the paste was then placed into the calorimeter and the rate of the heat liberation was measured at $40{ }^{\circ} \mathrm{C}$ for 7 days. 
The extra powder sample as obtained for the XRD test was used to measure the $\mathrm{pH}$ of the hardened pastes at the age of $3,7,28,56$ and 91 days. Solution samples were prepared with 1 part of powder and 10 parts of distilled water. These powder/water mixes were kept rotating on a roller table for $24 \mathrm{~h}$ after which time they were placed in a centrifuge operating at $5000 \mathrm{rpm}$ for $5 \mathrm{~min}$ to separate the solids from the liquid. The liquid was transferred to a new bottle where the $\mathrm{pH}$ was measured using a hand held $\mathrm{pH}$ probe.

A PANalytical's XPert Pro X-ray diffractometer with nickelfiltered $\mathrm{CuK \alpha}$ l radiation $1.5405 \AA, 40 \mathrm{kV}$ voltage and $40 \mathrm{~mA}$ current with scanning speed of $0.5^{\circ} / \mathrm{min}$ and step size of $0.02^{\circ} / \mathrm{min}$ was used to identify crystalline phases presented in the samples.

A Simultaneous Thermal Analyser STA 449C Jupiter was employed to measure some physical properties of the material as a function of the temperature change. For thermogravimetric analysis (TGA), the samples were heated in an atmosphere of nitrogen at $10^{\circ}$ $\mathrm{C} / \mathrm{min}$ up to $1000^{\circ} \mathrm{C}$.

A Jeol JSM 6400 scanning electron microscope (SEM) fitted with a Link EDS Analyzer was used to examine the microstructure of 28 days samples of M2, M3, M4 and M5. 


\section{Test results and discussions}

\subsection{Mini slump}

The mini slump value of the activated slag decreased with increasing Blaine surface area for the same w/b ratio, as shown in Fig 1, which is mainly due to the increased water demand of the finer slag. It can also be observed that the workability of the paste made with the fine slag was approximately the same as that made with the PC (Fig 1).

Yang et al. [39] reported that the initial flow of an alkali activated mortar decreased with an increase of $\mathrm{Na}_{2} \mathrm{O}$ content when they used sodium silicate powder as an activator. Yang and Song [40] used sodium silicate powder and sodium hydroxide powder to produce AAS mortars. They found that the initial flow of the AAS mortar slightly decreased with an increase in the amount of sodium silicate. However, as shown in Fig 1, in the current work the activator concentration, had no obvious effect on the mini slump value of the pastes manufactured with the slag of the same fineness, indicating that, unlike sodium silicate, the concentration of sodium sulfate has little effect on the rheological properties of sodium sulfate activated slags. The results of the current investigation would suggest that the mini slump value of sodium sulfate activated slag depends primarily on the fineness of the slag used and is less sensitive to the concentration of sodium sulfate. 


\subsection{Heat of hydration}

The isothermal conduction calorimeter is considered as a useful technique for studying the early hydration of cemenitious materials. The hydration process is usually divided into five stages, namely, initial reaction, induction, acceleration, deceleration and decay. Four peaks are normally be identified for PCs. From Fig 2, it can be seen that, although similar stages still could be identified, only two peaks can be seen, indicating a different hydration mechanisms. The first peak could be attributed to the wetting of slag and some initial reaction of slag. The second peak could be attributed to the main hydration reaction, forming C-S-H (I) and ettringite. It can also be noticed that during the induction period, an endothermic region can be recognized, which could be attributed to the fact that sodium sulfate is a good endothermic agent and it can absorb latent heat generated from the hydration reaction of the slag. As the magnitude of the endothermic region is related to the quantity of sodium sulfate, this information could be used indirectly to assess the reactivity of the slag. Further discussion is given below.

For the slags activated with $1 \%$ concentration $\mathrm{Na}_{2} \mathrm{SO}_{4}$, it is obvious that the fineness affected the rate of the heat generated (Fig 2). The heat flow evolution of M3 is characterized by a relatively shorter dormant 
period and an intense and sharp main hydration peak. The M2 exhibits a relatively longer dormant period, a lower heat flow and a wider main hydration peak. The main peak value of the heat evolution of M3 was approximately $80.5 \%$ higher than that of M2. It can be concluded that increased fineness accelerated the rate of heat evolution for reaching the main peak value. Moreover, the time required for M3 to reach the main peak was approximately $18.85 \mathrm{~h}$ less than that of M2. It can also be observed that during the induction period, an endothermic region appears for both M2 and M3. However, the endothermic region of M2 is larger than that of M3. As this endothermic region is attributed to the heat absorbed by sodium sulfate, the larger endothermic region from M2 would indicate that more sodium sulfate is available than M3. This suggests a lesser degree of reaction between the slag and sodium sulfate in M2, which also correlates well with the compressive strength results, shown in Fig 5. A similar pattern could be observed in the slags activated with $3 \% \mathrm{Na}_{2} \mathrm{SO}_{4}$.

The above results indicate that the fine slag altered the hydration process and caused an increase in the rate of hydration and shortened the required hydration time. It is worth mentioning that the current pattern of the hydration heat of different slags fineness agrees with the previous results reported for sodium hydroxide activated slags [41]. 
Figure 2 also shows the sodium sulfate activated slags made with the coarse $\left(2500 \mathrm{~cm}^{2} / \mathrm{g}\right)$ slag using the two levels of activator concentration. The heat flow for sample $\mathrm{M} 4\left(3 \% \mathrm{Na}_{2} \mathrm{O}\right.$ equivalent) is characterized by a relatively short dormant period and an intense main hydration peak. The M2 (1\% $\mathrm{Na}_{2} \mathrm{O}$ equivalent) exhibits a slightly longer dormant period, a lower heat flow and a slightly wider main hydration peak. The rate of hydration of M4 surpassed that of M2 and promoted the hydraulic reactivity. The heat evolved in M4 was approximatly53.3\% higher than that of M2 and the time required for M4 to reach the main peak was approximately $22 \mathrm{~h}$ less than that of M2. A similar pattern can be observed in Fig 2 for the sodium sulfate activated slag manufactured with the fine slag $\left(5000 \mathrm{~cm}^{2} / \mathrm{g}\right)$.

These results indicated that the higher activator concentration caused a slight increase in heat of hydration and a slight decrease in hydration time. It is worth mentioning that the heat liberation curves of the system studied here are similar to those of a $\mathrm{NaOH}$ system, except that the dormant period in the current sodium sulfate is more obvious and longer [42].

\section{$3.3 \mathrm{pH}$ values}


In construction, it is important to maintain a high $\mathrm{pH}$ to form a passive protection layer on the surface of reinforcing steel and reduce corrosion risk. However, as mentioned before, to immobilize nuclear wastes containing aluminium, zeolites and glass, a cementitious system with a lower $\mathrm{pH}$ is preferred. In the activated slag system, the $\mathrm{pH}$ value of the solution plays an important role in the hydration process [43] and determines the nature of the hydration products formed $[44,45]$. It has been reported that the $\mathrm{pH}$ should be higher than 11.5 in order to activate the hydration of the slag effectively and when the $\mathrm{pH}$ is lower than 9.5, the hydration of slag cannot proceed [43]. Higher $\mathrm{pH}$ values usually lead to better slag activation [44, 46-48], shorter setting times and higher mechanical strengths [46]. Lower $\mathrm{pH}$ values $(<12)$ would, on the other hand, delay the activation process [46].

In this research the slag had a $\mathrm{pH}$ value of approximately 11.5 whilst that of the $\mathrm{Na}_{2} \mathrm{SO}_{4}$ solutions were 8.3 and 8.2 for 1 and $3 \% \mathrm{Na}_{2} \mathrm{O}$ equivalents, respectively. However, when $\mathrm{Na}_{2} \mathrm{SO}_{4}$ solutions were used to activate the slag, the $\mathrm{pH}$ value of the pastes appeared to be dependent on the concentration of the activators.

Figures 3, 4 and Table 3 show the $\mathrm{pH}$ of the 3, 7, 28, 56 and 91 days samples. It can be seen that an increase in sodium sulfate concentration leads to an increase in paste $\mathrm{pH}$ regardless of the fineness 
of the slag. These results indicated that even though the $\mathrm{pH}$ of the two sodium sulfate solutions used was very similar (around 8) the resultant $\mathrm{pH}$ of the activated slag pastes were different (between $\mathrm{pH} 12$ and 13) and this would cause a higher slag activation. On the other hand, it can be noticed that the $\mathrm{pH}$ of the hardened paste was not affected by the fineness of the slag, which along with the compressive strength results (to be discussed below), suggesting that the strength of $\mathrm{Na}_{2} \mathrm{SO}_{4}$ slags could be increased by increasing the fineness of the slag without increasing the $\mathrm{pH}$ of the hardened pastes.

Figures 3 and 4 also show that the $\mathrm{PC}$ paste had $\mathrm{pH}$ values $>12.7$ whilst the activated slags had $\mathrm{pH}$ values ranging between 12.2 and 12.5 depending on the activator concentration.

\subsection{Compressive strength}

Generally, the reactivity and strength development of slag depend on various factors such as composition, glass content, particle size distribution, activator type and alkali content [21, 49].

Figure 5 illustrates the compressive strength results of the PC and activated slags. The compressive strength of all the pastes increased over the different curing periods with time, with the PC paste giving much higher compressive strength. The compressive strength of the activated 
slags appeared to be highly dependent on slag fineness and activator concentration.

\subsubsection{Effect of slag fineness on compressive strength}

Generally, the fine slag should be more reactive, which can lead to the increase of strength, regardless of the type of activator used [50]. The results presented in Fig 5 show that for a given concentration of the activator with the increase of the slag fineness the strength of sodium sulfate activated slags increased at all ages. After 3, 7, 28, 56 and 91 days hydration, the compressive strength of M3was 137.4, 85.5, 51.7, 45.6 and $32.2 \%$ higher than that of M2, respectively. Similarly, the compressive strength of M5 was 138.1,72.7, 49.2, 37.5 and 27\% higher than that of M4 after the same periods of hydration. The above results are corroborated by previously reported work by other researchers based on slags activated by different other types of activators. Brough and Atkinson [22] reported that an increase in Blaine fineness from 3320 to $5500 \mathrm{~cm}^{2} / \mathrm{g}$ led to an increase in mechanical strength of the sodium silicate activated slag. Wang et al. [21] reported that the fineness to achieve the most desirable strength properties of sodium silicate activated slag depends on the type of slag and varies between 4000 and $5500 \mathrm{~cm}^{2} / \mathrm{g}$ for basic slag and $4500-6500 \mathrm{~cm}^{2} / \mathrm{g}$ for acid and neutral slags. Other 
authors reported that strength of sodium silicate and sodium hydroxide activated slag increased with the increase in slag fineness [40] up to 6000 $\mathrm{cm}^{2} / \mathrm{g}$ [51]. Gruskovnjak et al. [52] used a solid waterglass, solid Nametasilicate pentahydrate $\left(\mathrm{Na}_{2} \mathrm{SiO}_{3} \cdot 5 \mathrm{H}_{2} \mathrm{O}\right)$ as a source of activator to activate slag. They reported that the high fineness of the slag represented a further important factor for fast reactivity, in which the small slag particles $(<2 \mu \mathrm{m})$ were completely hydrated within the first $24 \mathrm{~h}$ after mixing, whereas hydration of the larger particles was much slower. Other authors [29] believed that the effect of slag specific surface area increment on mechanical strength depends on the type of activator.

\subsubsection{Effect of concentration of activator on compressive strength}

From Fig 5, it can be seen that, for a given fineness, only slight increase in the compressive strength of $\mathrm{Na}_{2} \mathrm{SO}_{4}$ activated slags has been achieved for the samples activated with $3 \% \mathrm{Na}_{2} \mathrm{O}$ equivalent $\mathrm{Na}_{2} \mathrm{SO}_{4}$ compared to those activated with $1 \% \mathrm{Na}_{2} \mathrm{O}$ equivalent $\mathrm{Na}_{2} \mathrm{SO}_{4}$. The highest increase in compressive strength was found at 3 and 7 days, whilst at later ages, from 28 to 91 days, the strength tended to converge, which indicate that increasing the concentration of sodium sulfate is only slightly effective during the early stage of hydration. These compressive strength results confirmed the calorimetry results and showed that the 
higher activator concentration increases the slag activation during the early stage of hydration. This is also corroborated by reports in the literature where many authors have reported that increasing activator concentration leads to an increase in mechanical strength of alkaliactivated cementitious materials $[18,26,28,31,40,50,53-59]$ and leads to decrease in setting time [31].

The comparison of the compressive strength of M2 (coarse slag + $1 \% \mathrm{Na}_{2} \mathrm{SO}_{4}$ ), M3 (fine slag $+1 \% \mathrm{Na}_{2} \mathrm{SO}_{4}$ ), $\mathrm{M} 4$ (coarse slag $+3 \% \mathrm{Na}_{2} \mathrm{SO}_{4}$ ) and M5 (fine slag $+3 \% \mathrm{Na}_{2} \mathrm{SO}_{4}$ ) indicated that the compressive strength of these four mixtures follow the order of $\mathrm{M} 5>\mathrm{M} 3>\mathrm{M} 4>\mathrm{M} 2$ at all the ages. In addition, it could be observed that, for a given slag fineness, doubling the concentration of sodium sulfate from $1 \%\left(\mathrm{Na}_{2} \mathrm{O}\right.$ equivalent) to $3 \%$ only slightly increased the compressive strength of the activated slags, whereas for a given concentration of sodium sulfate, doubling the slag fineness from $2500 \mathrm{~cm}^{2} / \mathrm{g}$ to $5000 \mathrm{~cm}^{2} / \mathrm{g}$ resulted in a significant increase of the compressive strength at all ages. This would suggest that increasing the fineness of slag is more effective than increasing the concentration of $\mathrm{Na}_{2} \mathrm{SO}_{4}$ for increasing both the early and long-term strength of $\mathrm{Na}_{2} \mathrm{SO}_{4}$ activated slags. It should be noticed that the pervious $\mathrm{pH}$ results showed that the $\mathrm{pH}$ of the activated slag was not affected by the fineness of the slag when the same concentration of $\mathrm{Na}_{2} \mathrm{SO}_{4}$ was used. 
Therefore, based on the $\mathrm{pH}$ and the compressive strength results, it could be concluded that by increasing the fineness of the slag, both the early and long-term compressive strength of $\mathrm{Na}_{2} \mathrm{SO}_{4}$ activated slag could be improved without increasing the $\mathrm{pH}$ of the hardened matrix.

\subsection{Crystalline phases}

The wide diffusive amorphous hump between 25 to $35^{\circ} 2 \theta$ (Fig 6) indicates that the slag is mostly amorphous. Small reflections for akermanite $\left(\mathrm{Ca}_{2} \mathrm{Mg}\left(\mathrm{Si}_{2} \mathrm{O}_{7}\right)\right)$, gehlenite $\left(\mathrm{Ca}_{2} \mathrm{Al}(\mathrm{AlSiO})_{7}\right)$ and merwinite $\left(\mathrm{Ca}_{3} \mathrm{Mg}\left(\mathrm{SiO}_{4}\right)_{2}\right)$ were identified.

Figures 7 to 11 show the XRD patterns of the activated slag mixtures at different ages. Similar patterns could be identified for all the mixtures. The amorphous hump centered around $30^{\circ} 2 \theta$ indicates that the activated slags are relatively amorphous and lack long-range order. Small amounts of ettringite $\left(\mathrm{Ca}_{6} \mathrm{Al}_{2}\left(\mathrm{SO}_{4}\right)_{3}(\mathrm{OH})_{12} \cdot 26 \mathrm{H}_{2} \mathrm{O}\right)$ were detected in all the samples and more were detected in samples containing a higher dosage of sodium sulfate, especially at early ages. This may be part of the reason that a higher compressive strength at early ages was observed in the activated slag pastes with higher dosage of sodium sulfate compared with those made with lower dosage. Intense reflections for CSH type I (CSH I), which overlaps with those of calcite, could be seen in all the 
samples and the intensity of these peaks increased slightly with ages. Less intense CSH I reflections were seen in the activated slags with the lower activator dosage compared to those with the higher dosage. Previous studies by other researchers have also detected CSH as the main reaction product of AAS [28, 40, 43, 44, 60-66]. Akermanite was again present. Hydrotalcite $\left(\mathrm{Mg}_{6} \mathrm{Al}_{12} \mathrm{CO}_{3}(\mathrm{OH})_{16} \cdot 4 \mathrm{H}_{2} \mathrm{O}\right)$ was also detected with the magnesium coming from the slag. This phase detected before in PC/slag blends [67] and it was also reported in the slags activated with $\mathrm{NaOH}[44$, $60,68,69-71]$, waterglass [69], sodium silicate $\left(4 \% \mathrm{Na}_{2} \mathrm{O}, 8 \% \mathrm{Na}_{2} \mathrm{O}\right)$ [72] and solid Na-metasilicate pentahydrate $\left(\mathrm{Na}_{2} \mathrm{SiO}_{3} \cdot 5 \mathrm{H}_{2} \mathrm{O}\right)$ [73]. Calcium hydroxide $(\mathrm{CH})$ was not detected.

\subsection{Thermogravimetric analysis}

Thermogravimetric analysis (TGA) and derivative thermogravimetry (DTG) were used to assess weight loss during the controlled heating of the samples in order to identify phases present. The weight loss and derivative weight loss curves in the range $20-1000{ }^{\circ} \mathrm{C}$ for the M5 samples hydrated for3, 7, 28, 56 and 91 days are shown in Fig 12. The main DTG peak centered at approximately $100{ }^{\circ} \mathrm{C}$ is caused by the maximum rate of dehydration from $\mathrm{CSH}$ [2] but this peak could also be due to a small amount of dehydration from ettringite [74]. The gradual 
weight loss after this main peak is due to the slow further dehydration of $\mathrm{CSH}$ which occurs up to approximately $600{ }^{\circ} \mathrm{C}$ [2]. As curing time progresses, the amount of weight loss, and thus the amount of the hydration products increases. The small DTG peaks at approximately 690 ${ }^{\circ} \mathrm{C}$ and $820{ }^{\circ} \mathrm{C}$ are due to decarbonation of calcite $\left(\mathrm{CaCO}_{3}\right)$. No weight loss or DTG peak was present for $\mathrm{Ca}(\mathrm{OH})_{2}$ (usually centered at approximately $450{ }^{\circ} \mathrm{C}$ ) . These results are in agreement with those obtained by XRD.

Figure 13 represents the TGA/DTG of hardened activated slag pastes of M2 and M3 after hydration of 3 days. From Fig 13 it is possible to point out that when hardened paste containing fine slag, the content of $\mathrm{CSH}$ and hydration products are higher than that in the case of the paste containing coarse slag. This may be part of the reason that a higher compressive strength was observed from the activated slag made with fine slag compared to that with coarse slag.

Figure 14 represents the amount of water bound by the hydration products in the M3 and M5 samples after hydration for 3, 7, 56 and 91 days. The amount of bound water is greater for the pastes activated with $3 \% \mathrm{Na}_{2} \mathrm{O}$ equivalent sodium sulfate compared with those activated with $1 \% \mathrm{Na}_{2} \mathrm{O}$ equivalent sodium sulfate indicating that the higher dosage of sodium sulfate caused the formation of more hydration products. 


\subsection{Microstructural analysis}

Figure 15 shows SEM micrographs of fracture surfaces of the activated slag after 28 days hydration. It can be seen from Fig 15 (a) that sample M2 (prepared with the coarse slag and lower concentration of activator) has a less dense and open microstructure and shows a limited amount of CSH gel, needles (which could be the ettringite) and other hydration products. In contrast, Fig 15 (b) showing sample M3 (prepared with the fine slag and lower concentration of activator) appeared to have a denser microstructure and contained more needles of what is probably ettringite.

Figures 15 (c) and (d) show the microstructures after activation with the higher dosage of sodium sulfate $\left(3 \% \mathrm{Na}_{2} \mathrm{O}\right.$ equivalent). Compared to M2, more needles of what are probably ettringite can be seen for the samples containing both the coarse Fig 15 (c) and the fine Fig 15 (d) slag and the higher activator dosage appeared to produce a more dense microstructure. However, it seems more needles could be observed in M3 sample. Figure 15 (e) shows fine detail of needles of what is probably ettringite and shows the hexagonal columnar structure which is the characteristic of this mineral [2]. 
Figure 16 shows EDS images of the spots in Fig 15 (e) marked 1 and 2. Spot 1 (main matrix) is mostly C-S-H for which the EDS image shows the dominant peaks for $\mathrm{Ca}$ and $\mathrm{Si}$. Other minor peaks (such as $\mathrm{S}$, $\mathrm{Al}, \mathrm{Mg}$ and $\mathrm{Na}$ ) were presented either due to their incorporation into the $\mathrm{CSH}$ structure (which is most likely for $\mathrm{Al}$ ) or because of the penetration of the electron beam through the particle under investigation into other nearby material. The latter was more likely. Figure 16 (b) shows the EDS image of spot 2 in Fig 15(e) which is thought to be ettringite. This image shows the presence of a significant $\mathrm{Si}$ peak. Ettringite $\left(\mathrm{Ca}_{6} \mathrm{Al}_{2}\left(\mathrm{SO}_{4}\right)_{3}\right.$ $\left.(\mathrm{OH})_{12} \cdot 26 \mathrm{H}_{2} \mathrm{O}\right)$ as formulated does not contain $\mathrm{Si}$; so the $\mathrm{Si}$ identified here has probably been detected from the CSH behind the particle of ettringite being examined. This is known to happen because, upon impacting on the surface of the material being examined, the electron beam in an electron microscope can spread up to approximately $6 \mu \mathrm{m}$ in diameter [75]. The other main elements detected by EDS in spot 2 are S and $\mathrm{Al}$ which are the other principal elements in ettringite.

\section{Conclusions}

Based on the results reported in this study, the following conclusions can be drawn: 
1. The paste workability of sodium sulfate activated slag, in terms of mini-slump value, depends primarily on the fineness of the slag used and is less sensitive to the change of the concentration of sodium sulfate.

2. Compared to PC systems, similar hydration stages have been identified from sodium activated slags. Increasing both the slag fineness and the sodium sulfate concentration can increase the rate of heat evolution of the sodium sulfate activated slags.

3. Whilst the $\mathrm{pH}$ of the hardened paste was not affected by the fineness of the slag, it slightly increased with higher dosage of sodium sulfate. Overall, the $\mathrm{pH}$ of sodium sulfate activated slag is lower than that of PC systems, which could potentially benefit some special applications such as immobilizing certain types of nuclear wastes containing reactive metals and resins.

4. Increasing the fineness of slag is a more effective approach than increasing the concentration of $\mathrm{Na}_{2} \mathrm{SO}_{4}$ for improving both the early and long-term strength of $\mathrm{Na}_{2} \mathrm{SO}_{4}$ activated slags. In addition, by increasing the fineness of the slag instead of increasing the concentration of sodium sulfate, both the early and long-term compressive strength of $\mathrm{Na}_{2} \mathrm{SO}_{4}$ activated slag can be improved without increasing the $\mathrm{pH}$ of the hardened matrix. In general, the 
compressive strength of sodium sulfate activated slags is still lower than the corresponding PC system.

5. Irrespective of slag fineness and sodium sulfate concentration, the main hydration product of sodium sulfate activated slag was CSH(I) but significant quantities of ettringite were also detected.

\section{Acknowledgement}

Dr Alaa.M. Rashad was sponsored by Egyptian government for his academic visit to Queen's University Belfast, U.K. The slag used in this research was supplied by Hanson Cement. This, and the facilities provided by the School of Planning, Architecture and Civil Engineering at Queen's University Belfast, are also gratefully acknowledged.

\section{References}

1. Shi C. and Qian J., (2000) "High performance cementing materials from industrial slags - a review", Resource, Conservation and Recycling, 29, 195-207.

2. Taylor H. F. W., (1997) "Cement chemistry", Thomas Telford, London, 1997.

3. Palomo À., Fernández-Jiménez A., López-Hombrados C. and Lieyda J.L., (2007) "Railway sleepers made of alkali activated fly 
ash concrete", Revista Ingeniería de Construcción, Vol. 22, No. 2, $75-80$.

4. Malhotra V. M. and Mehta P. K., (2005) "High-performance, highvolume fly ash concrete: materials, mixture, proportioning, properties, construction practice, and case histories", $2^{\text {nd }}$ edn. Supplementary cementing materials for sustainable development incorporated, Ottawa, 1-124.

5. Sakulich A.R., Miller S. and Barsoum M.W., (2010) "Chemical and microstructural characterization of 20-month-old alkaliactivated slag cements", J. Am. Ceram. Soc., 93, 6, 1741-1784.

6. Roy D. M., (1999) "Alkali-activated cements opportunities and challenges", Cement and Concrete Research, 29, 249-254.

7. Glukhovsky V. D., Rostovskaja G. S. and Rumyna G. V., (1980) "High strength slag-alkaline cements", 7th Int. Congress Chemistry Cement, Paris, Vol.3, ppV164-V168.

8. Krivenko P. V., (1992) "Alkaline cements", in 9th International Congress Chemistry Cement, New Delhi, India, Vol. IV, 482-88.

9. Glukhovsky V. D., (1980) "High strength slag alkaline cements", In: proceedings of the $7^{\text {th }}$ International congress on the chemistry of cement, Paris, 1980. 
10. Glukhovsky V. D. and Pakhomov V. A., (1978) "Slag-alkali cements and concretes", Russia: Budivelnik Publishers.

11. Davidovits J., (1994) "Properties of geopolymer cements”, Proc. Of the $1^{\text {st }}$ Int. Confer. Alkali. Cem. And con., VIPOL Stock Company, Kiev, Ukraine, Vol. I, 131-149.

12. Chatterjiee A. K., (1992) "Special and new cement", Proc. of $9^{\text {th }}$ Int. Congr. Chem. Cem., National council for Cement and Building Materials (NCB), New Delhi, India, Vol. I, 177.

13. Malolepszy J., (1986) "Activation of synthetic melitite slags by alkalis", Proceedings of Eight International congress on Chemistry of cements, Brazil, IV, 104-107.

14.Shi C. J., (1989) "Alkali-phosphorous slag cement", J. Southeast Univ., 19(1), 141-144.

15. Dai L. L., and Chen J. N., (1988) "Alkali-slag-fly ash cement”, Bull. Chin. Ceram. Soc., 16(1), 25-32.

16. Yuan R. Z., Qiong Y. and Quyang S. X., (1987) "Structure, hydration activity and mechanism of activation of slag”, J. Wuhan Univ. Ind. Technol. 3, 297-302.

17. Pu X. C., Gan C. C. and Wu L., (1989) "Properties of alkali-slag cement concrete", J. Chin. Ceram. Soc., 5, 5-10. 
18. Parameswaran P. S. and Chatterjee A. K., (1986) Proc. 8th Int. Congress on the Chemistry of cement (Rio de Janeiro), Abla Gráfica e Editoria Ltda, Rio de Janeiro, Vol. 4, 86-91.

19. Tango C. E. S and Valdergorin E. Y. L., (1992) Proc. 9th Int. Congress on the chemistry of cement, National Council of Cement and Building Materials, New Delhi, Vol. 3, 101-107.

20. Roy A., Schilling P. J., Eaton H. C., Malone P. G., Brabston W. N. and Wakeley L. D., (1992) "Early Hydration of a Portland Cement in Water", J. Am. Ceram. Soc., 75, (12), 3233-3240.

21. Wang S-D, Scrivener K. L. and Pratt P. L., (1994) "Factors affecting the strength of alkali-activated slag", Cement Concrete Research, 24, 1033-43.

22. Brough A. R. and Atkinson A., (2002) "Sodium silicate-based, alkali-activated slag mortar: Part 1. Strength, hydration and microstructure", Cement and Concrete Research, 32, 865-879.

23. Escalante-Garcia J. I., Méndez-Nonell J., Gorokhovsky A., FraireLuna P. E., Mancha-Molinar H. and Mendoza-Suarez G., (2002) "Reactividad y propiedades mecánicas de scoria de alto horno activada por alkalis", Bol. Soc. Esp. Cerám. Vidrio, [in Spain],41, (5), 451-458. 
24. Escalante-Garcia J. I., Fuentes A. F., Gorokhovsky A., FraireLuna P. E. and Mendoza-Suarez G., (2003) "Hydration products and reactivity of blast-furnace slag activated by various alkalis", J. Am. Ceram. Soc., 86, (12), 2148-53.

25. Brough A. R. and Atkinson A., (2002) "Sodium silicate-based alkali-activated slag mortars, Part I, strength, hydration and microstructure", Cement and Concrete Research, 32, 865-79.

26. Katz A., (1998) "Microscopic study of alkali-activation fly ash", Cement and Concrete Research, 28, 197-208.

27.Pu X.C., Gan C.C., Wang S. D., Yang C. H., (1988) Summary Reports of Research on "Alkali-Activated Slag Cement and Concrete", Volumes 1-6, Chongqing Institute of Architecture and Engineering, Chongqing.

28. García E., Campos-Venegas K., Gorokhovsky A. and Fernández A., (2006) "Cementitious composites of pulverized fuel ash and blast furnace slag activated by sodium silicate: effect of $\mathrm{Na}_{2} \mathrm{O}$ concentration and modulus", Advances in Applied Ceramics, Vol. 105, No. 4, pp 201-207.

29. Fernández-Jiménez A., Palomo J. G. and Puertas F., (1999) "Alkali-activated slag mortars mechanical strength behavior", Cement and Concrete Research, 29, 1313-1321. 
30.Bakharev T., Sanjayan J. and Cheny Y-B., (1999) "Alkaliactivation of Australian slag cements", Cement and Concrete Research, 29, 113-20.

31.Atiş Cengiz Duran, Bilim Cahit, Çelik Özlem and Karahan Okan, (2009) "Influence of activator on the strength and drying shrinkage of alkali-activated slag mortar", Construction and Building Materials, 23, 548-555.

32.Krizan D. and Zivanovic B., (2002) "Effect of dosage and modulus of water glass on early hydration of alkali-slag cements", Cement and Concrete Research, 32, 1181-8.

33.Shi C. J., Krivenko P. V. and Roy D. M., (2005) "Alkali-activated cements and concretes", Taylor \& Francis, 376.

34.Habert G., de Lacaillerie J. B. d'Espinose and Roussel N., (2011) "An environmental evaluation of geopolymer based concrete production: reviewing current research trends", Journal of Cleaner Production, 19, 1229-1238.

35. Rashad A. M., Bai Y., Basheer P. A. M., Collier N. C. and Milestone N. B., (2012) "Chemical and mechanical stability of sodium sulfate activated slag after exposure to elevated temperature", Cement and Concrete Research, 42, 333-343. 
36.Bai, Y., Milestone, N. B. and Yang, C. H., (2006) "Sodium Sulphate Activated GGBS/PFA and Its Potential as a Nuclear Waste Immobilisation Matrix", $29^{\text {th }}$ International Symposium on the Scientific Basis for Nuclear Waste Management, Symposium Proceedings Volume 932, Editor: Pierre Van Iseghem, Materials Research Society, Symposium held Sept. 12-16, 2005, Ghent, Belgium, 759-766.

37. Milestone N. B., (Feb. 2006) "Reactions in cement encapsulated nuclear wastes: need for toolbox of different cement types", Advances in Applied Ceramics, 105, 1, 13-20.

38. Collins F. and Sanjayan J. G., (1998) "Early age strength and workability of slag pastes activated by $\mathrm{NaOH}$ and $\mathrm{Na}_{2} \mathrm{CO}_{3}{ }^{\prime \prime}$, Cement and Concrete Research, Vol. 28, No. 5, 655-664.

39. Yang K. H., Song J. K., Ashour A. F. and Lee E. T. (2008) "Properties of cementless mortars activated by sodium silicate", Construction and Building Materials, 22, 1981-1989.

40. Yang K.-H. and Song J.-K., (2009) "Workability loss and compressive strength development of cementless mortar activated by combination of sodium silicate and sodium hydroxide", Journal of Materials in Civil Engineering, ASCE, 21, No. 3, 119-127. 
41. Wang P. Z., Trettin R. and Rudert V., (2005) "Effect of fineness and particle size distribution of granulated blast-furnace slag on the hydraulic reactivity in cement systems", Advances in Cement Research, 17, No. 4, 161-166.

42. Kim J. C. and Hong S. Y., (2001) "Liquid concentration changes during slag cement hydration by alkali activation", Cement and Concrete Research, 31, 283-285.

43. Song S., Sohn D., Jennings H. M. and Mason T. O., (2000) "Hydration of alkali-activated ground granulated blast furnace slag", Journal of Materials Science, 35, 249-257.

44. Song S. and Jennings HM., (1999) "Pore solution chemistry of alkali-activated ground granulated blast - furnace slag", Cement and Concrete Research, 29, 159-170.

45. Gebhart R. F., (1995) "Survey of North American Portland cement", Cem Aggregates, 175-89.

46. Fernández-Jiménez A. and Puertas F., (2003) "Effect of activator mix on the hydration and strength behavior of alkali-activated slag cement", Advances in Cement Research, 15, Vo. 3, July, 129-136.

47. Zhou H., Wu X., Xu Z. and Tang M., (1993) "Kinetic study on hydration of alkali activated slag", Cement and Concrete Research, $23,6,1253-1258$. 
48. Chang J., (2003) "A study on the setting characteristics of sodium silicate activated slag pastes", Cement and Concrete Research, 33, 7, 1005-11.

49. Dongxu L., Zhongzi X., Zhimin L., Zhihua P. and Lin C., (2002) "The activation and hydration of glassy cementitious materials", Cement and Concrete Research, 32, 7, 1145-1152.

50. Talling B., (1989) "Effect of curing conditions on alkali-activated slags", 3rd Inter. Conf. on Fly-ash, Silica Fume, Slag and Natural Pozzolans in Concrete, Norway, Vol. 2, SP 114-72, pp1485-1500.

51. Gjorv O. E., (1989) "Alkali activation of a Norwegian granulated blast furnace slag", 3rd Inter. Conf. on Fly-ash, Silica Fume, Slag and Natural Pozzolans in Concrete, Norway, Vol. 2, SP114-73, pp1501-1517.

52. Gruskovnjak A., Lothenbach B., Holzer L., Figi R and Winnefeld F., (2006) "Hydration of alkali - activated slag: comparison with ordinary Portland cement", Advances in Cement Research, 18, No. $3,119-128$.

53. Douglas E. and Brandstetr J., (1990) "A preliminary study on the alkali activation of ground granulated blast - furnace slag", Cement and Concrete Research, 20 (5), 746-756. 
54. Pinto A. T., (2004) "Alkali-activated metakaolin based binders", $\mathrm{PhD}$ Thesis, University of Minho [only in Portuguese].

55. Wang H., Li H., Yan F., (2005) "Synthesis and mechanical properties of metakaolinite-based geopolymer", Colloids Surf, 268, $1-6$.

56. Wang S-D., (1991) "Review of recent research on alkafi-activated concrete in China", Mag. Cone. Res., 43(154), 29-35.

57. Isozaki K., Iwamoto S. and Nakagawa K., (1986) "Some properties of alkali-activated slag cement". 8th Int. Congr. Chem. Cem., Rio de Janeiro, Vol.6, pp395-399.

58. Metso J. and Kajaus E., (1983) "Activation of blast furnace slag by some inorganic materials". $1^{\text {st }}$ Int. Conf. on Fly-ash, Silica Fume, Slag and Natural Pozzolans in Concrete, Montbello, Canada, Vol. 2, pp1059-1073.

59. Andersson R., Gram H-E, Malolepszy J. and Deja J., (1988) "Alkali- activated slag", Swedish Cement and Concrete Research Institute, Stockholm, 104 ps.

60. Garcia J. I. E., Gorokhovsky A. V. Mendoza G. and Fuentes A. F., (2003) "Effect of geothermal waste on strength and microstructure of alkali-activated slag cement mortars", Cement and Concrete Research, 33, 1567-1574. 
61. Richardson, I. G., Brough, A. R., Groves, G. W. and Dobson, C. M., (1994) "The characterization of hardened alkali-activated blast-furnace slag pastes and the nature of the calcium silicate hydrate (C S H) phase", Cement and Concrete Research, 24, 81329.

62. Shi C., (1996) "Strength, pore structure and permeability of alkali-activated slag mortar", Cement and Concrete Research, Vol. 26, No. 12, 1789-1799.

63. Schneider, J., Cincotto, M. A. and Panepucci, H., (2001) ${ }^{\prime 29}$ Si and ${ }^{27} \mathrm{Al}$ high resolution NMR characterization of calcium silicate hydrate phases in activated blast-furnace slag pastes". Cement and Concrete Research, 31, 993-1001.

64. Fernandez-Jimenez, A. and Puertas, F., (2003) "Structure of calcium silicate hydrates formed in alkaline-activated slag: influence of the type of alkaline activator". J. Am. Ceram. Soc., 86, 1389.

65. Puertas, F., Fernandez-Jimenez, A. and Blanco-Varela, M. T., (2004) "Pore solution in alkali-activated slag cement pastes. Relation to the composition and structure of calcium silicate hydrate", Cement and Concrete Research, 34, 134-148. 
66. Schilling P. J., Roy A., Eaton H. C., Malone P. G. and Brabston W. N., (1994) "Microstructure, strength, and reaction products of ground granulated blast-furnace slag activated by highly concentrated NaOH solution", J. Mater. Res., Vol. 9, No. 188-197.

67.Richardson I. G. and Groves G. W., (Nov. 1992) "Microstructure and microanalysis of hardened cement pastes involving ground granulated blast-furnace slag", Journal of Materials Science, Vol. 27, No. 22, 6204-6212.

68.Puertas F., Ramirez M., Alonso S and Aázquez T., (2000) "Alkali activated flay ash/slag cement strength behavior and hydration products", Cement and Concrete Research, 30, 1625-1632.

69.Wang S.-D. and Scrivener K. L., (1995) "Hydration production of alkali activated slag cement", Cement and Concrete Research, Vol. 25, No. 3, 561-571.

70. Schilling P. J., Butler L. G., Roy A. and Eaton H. C., (1994) ${ }^{\prime 29} \mathrm{Si}$ and ${ }^{27} \mathrm{Al}$ MAS-NMR of NaOH-activated blast-furnace slag", Journal of the American Ceramic Society, Vol. 77, No. 9, 23632368.

71. Buchwald A., Hilbig H. and Kaps C., (2007) "Alkali-activated metakaolin-slag blend-performance and structure in dependence of their composition", J. Mater. Sci., 42, 3024-3032. 
72.Živica Vladimir, (2007) "Effects of type and dosage of alkaline activator and temperature on the properties of alkali-activated slag mixtures", Construction and Building Materials, 21, 1463-1469.

73. Gruskovnjal A., Lothenbach B., Holzer L., Figi R. and Winnefeld F., (2006) "Hydration of alkali-activated slag: comparison with ordinary Portland cement", Advances in Cement Research, 18, No. $3,119-128$.

74.Greene K. T., (1960) "Early hydration reactions of Portland cement", Proceedings of the Fourth International Symposium on Chem. Cements, Washington, 359-58.

75.Goodhew P. J., Humphreys F. J. and Beanland R., (2001) "Electron Microscopy and Analysis", London, Taylor and Francis. 
List of Tables

Table 1 Oxide composition of PC and slag ( $\%$ by mass) after calculation from XRF results

Table 2 Details of mix proportions

Table $3 \mathrm{pH}$ value of different pastes at different ages 
List of Figures

Figure 1 Mini slump value for various mixtures

Figure 2 Heat evolution curves of activated slag samples

Figure $3 \mathrm{pH}$ values for pastes made with PC and coarse slag activated with 1 and $3 \% \mathrm{Na}_{2} \mathrm{O}$ equivalent of $\mathrm{Na}_{2} \mathrm{SO}_{4}$

Figure $4 \mathrm{pH}$ values for pastes made with $\mathrm{PC}$ and fine slag activated with 1 and $3 \% \mathrm{Na}_{2} \mathrm{O}$ equivalent of $\mathrm{Na}_{2} \mathrm{SO}_{4}$

Figure 5 Compressive strength development of PC and activated slag pastes

Figure 6 X-Ray diffraction pattern for slag

Figure $7 \quad$ X-ray patterns of M2 pastes at different ages

Figure 8 X-ray patterns of M3 pastes at different ages

Figure 9 X-ray patterns of M4 pastes at different ages

Figure 10 X-ray patterns of M5 pastes at different ages

Figure 11 X-ray patterns of hardened activated slag pastes at age of 3 days

Figure 12 Thermo-gravimetric (TGA) and derivative thermogravimetric (DTG) curves for sample M5 at all ages

Figure 13 Thermo-gravimetric (TGA) and derivative thermogravimetric (DTG) curves for sample M2 and M3 at age of 3 days

Figure 14 Bound water in hydration products for samples of M3 and M5 
Figure 15 SEM micrographs of fracture surface of hardened activated slag pastes cured for 28 days

Figure 16 EDS images for the regions in Fig 15 (e) labeled 1 (a); and 2 (b) 


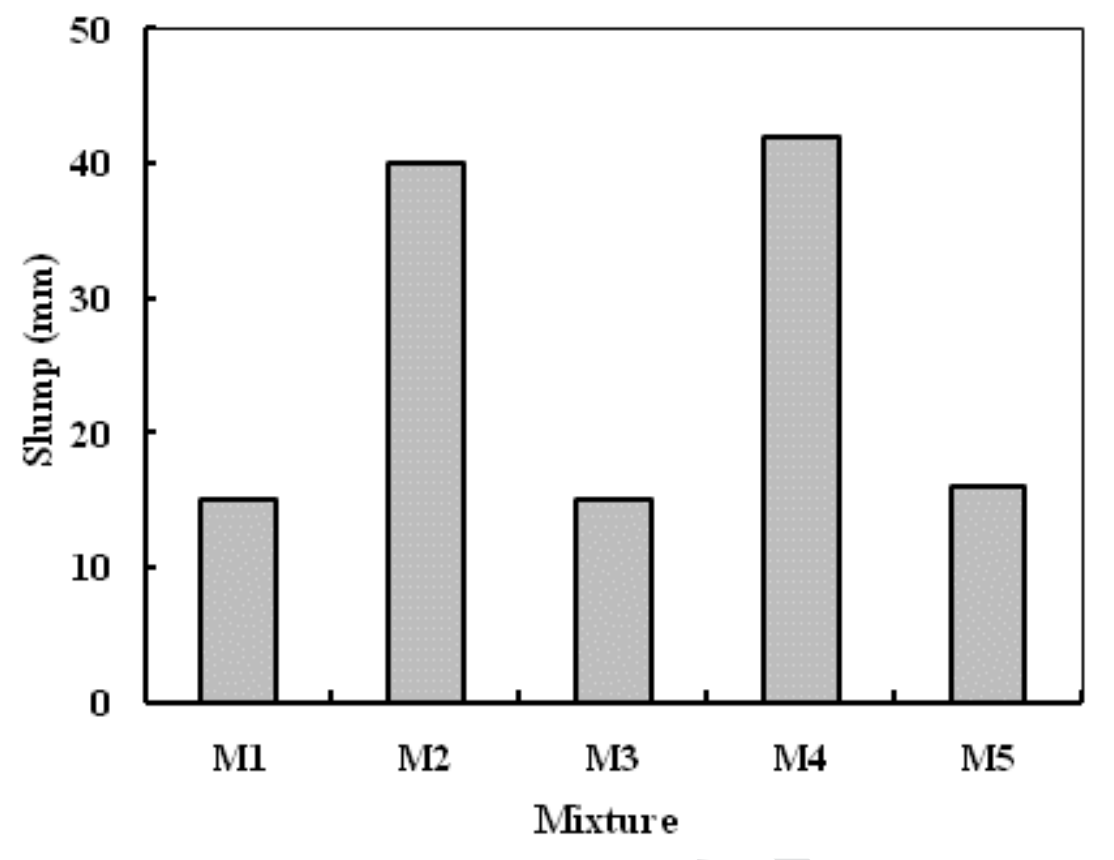

Fig. 1 Mini slump value for various mixtures 


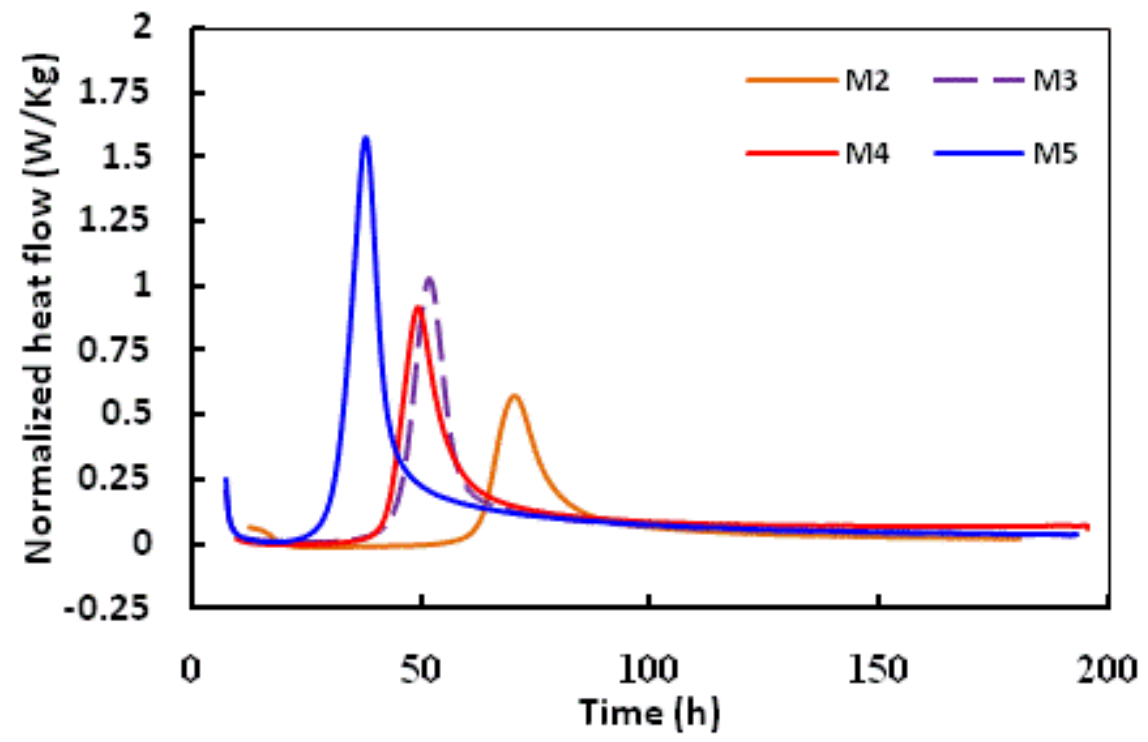

Fig. 2 Heat evolution curves of activated slag samples 


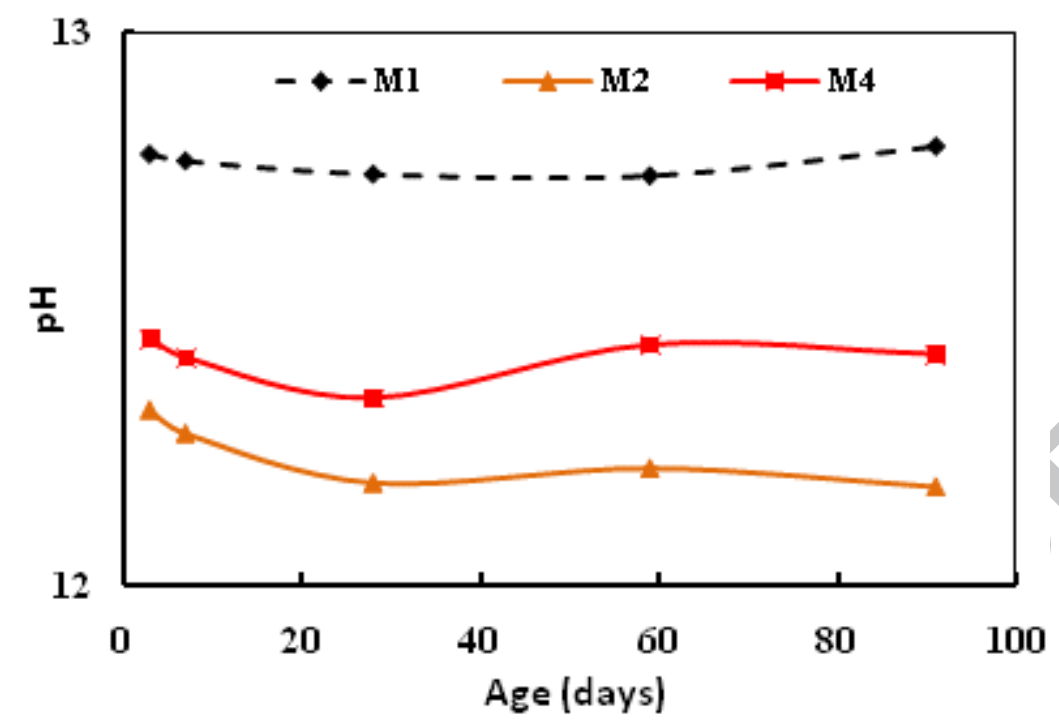

Fig. $3 \mathrm{pH}$ values for pastes made with $\mathrm{PC}$ and coarse slag activated with 1 and $3 \% \mathrm{Na}_{2} \mathrm{O}$ equivalent of $\mathrm{Na}_{2} \mathrm{SO}_{4}$ 


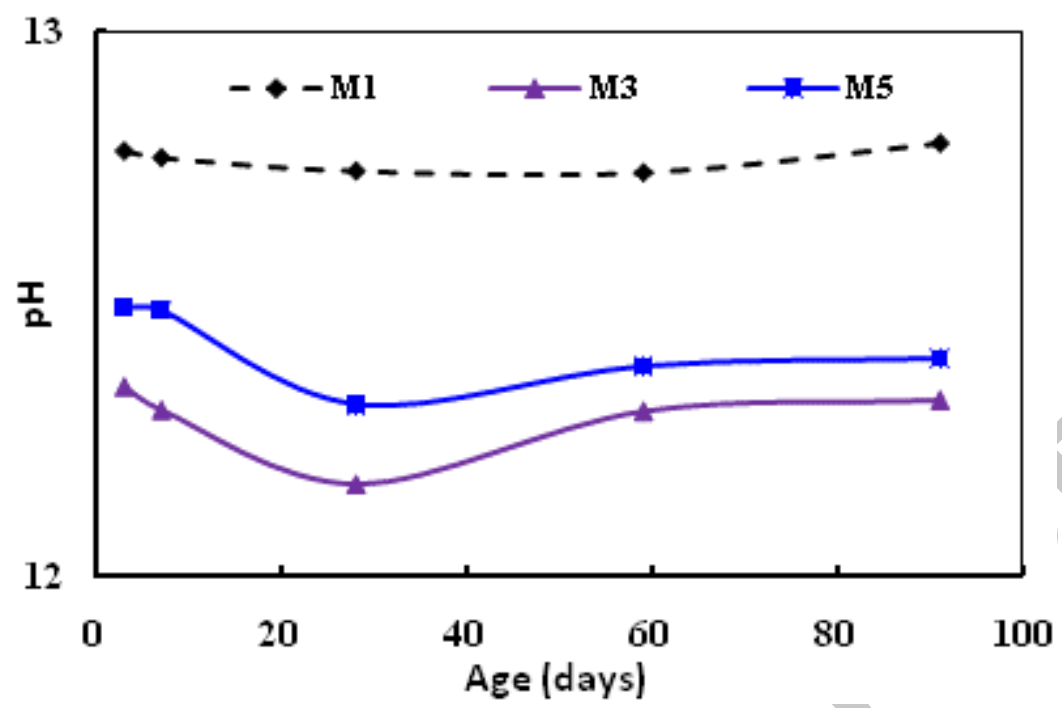

Fig. $4 \mathrm{pH}$ values for pastes made with $\mathrm{PC}$ and fine slag activated with 1 and $3 \% \mathrm{Na}_{2} \mathrm{O}$ equivalent of $\mathrm{Na}_{2} \mathrm{SO}_{4}$ 


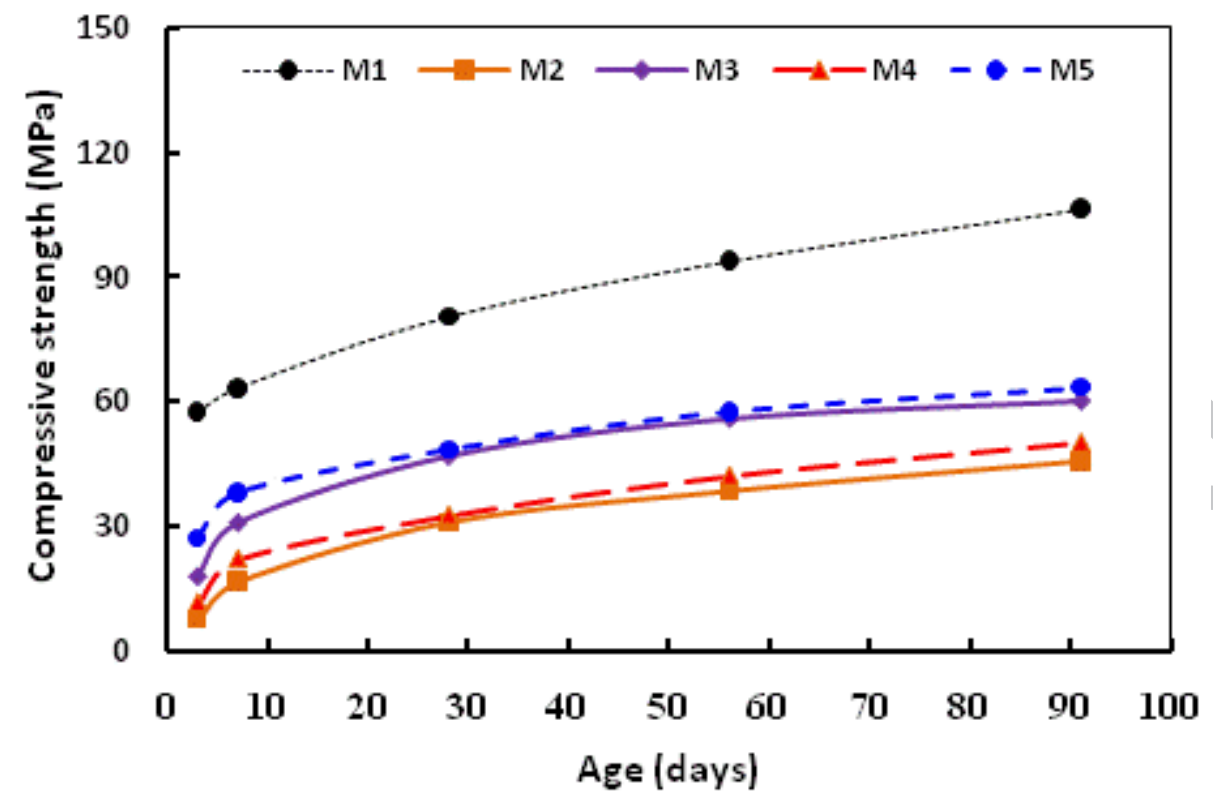

Fig. 5 Compressive strength development of PC and activated slag pastes 


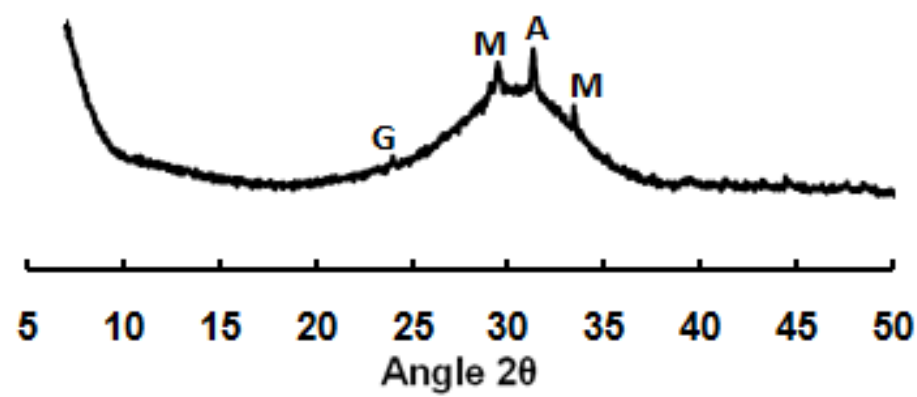

Key: G- Gehlenite $\mathrm{Ca}_{2} \mathrm{Al}\left(\mathrm{AlSiO}_{7}\right)$, A- Akermanite $\mathrm{Ca}_{2} \mathrm{Mg}\left(\mathrm{Si}_{2} \mathrm{O}_{7}\right)$, M-

Merwinite $\mathrm{Ca}_{3} \mathrm{Mg}\left(\mathrm{SiO}_{4}\right)_{2}$

Fig. 6 X-Ray diffraction pattern for slag 


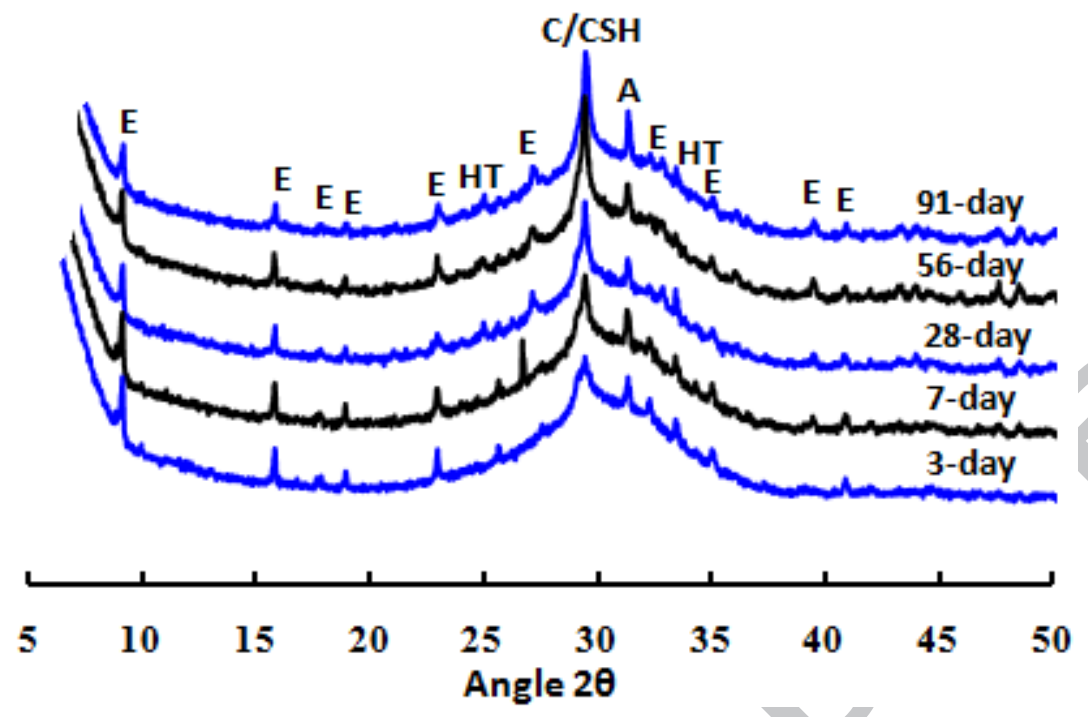

Key: $\mathrm{E}$ - ettringite $\mathrm{Ca}_{6} \mathrm{Al}_{2}\left(\mathrm{SO}_{4}\right)_{3}(\mathrm{OH})_{12} .26 \mathrm{H}_{2} \mathrm{O}, \mathrm{HT}$ - hydrotalcite $\mathrm{Mg}_{6} \mathrm{Al}_{2} \mathrm{CO}_{3}$

$(\mathrm{OH})_{16} \cdot 4 \mathrm{H}_{2} \mathrm{O}, \mathrm{C} / \mathrm{CSH}$ - overlapping calcite and calcium silicate hydrate, $\mathrm{A}$ akermanite $\mathrm{Ca}_{2} \mathrm{Mg}\left(\mathrm{Si}_{2} \mathrm{O}_{7}\right)$

Fig.7 X-ray patterns of M2 pastes at different ages 


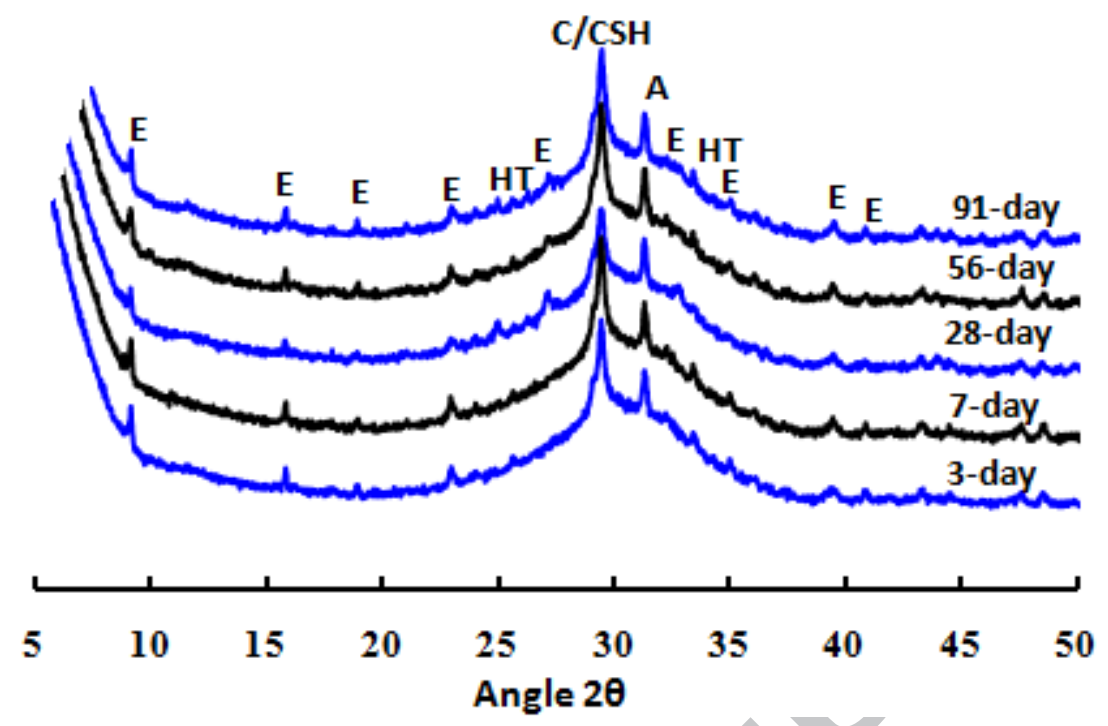

Key: $\mathrm{E}$ - ettringite $\mathrm{Ca}_{6} \mathrm{Al}_{2}\left(\mathrm{SO}_{4}\right)_{3}(\mathrm{OH})_{12} .26 \mathrm{H}_{2} \mathrm{O}, \mathrm{HT}$ - hydrotalcite $\mathrm{Mg}_{6} \mathrm{Al}_{2} \mathrm{CO}_{3}$

$(\mathrm{OH})_{16} .4 \mathrm{H}_{2} \mathrm{O}, \mathrm{C} / \mathrm{CSH}$ - overlapping calcite and calcium silicate hydrate, $\mathrm{A}$ akermanite $\mathrm{Ca}_{2} \mathrm{Mg}\left(\mathrm{Si}_{2} \mathrm{O}_{7}\right)$

Fig.8 X-ray patterns of M3 pastes at different ages 


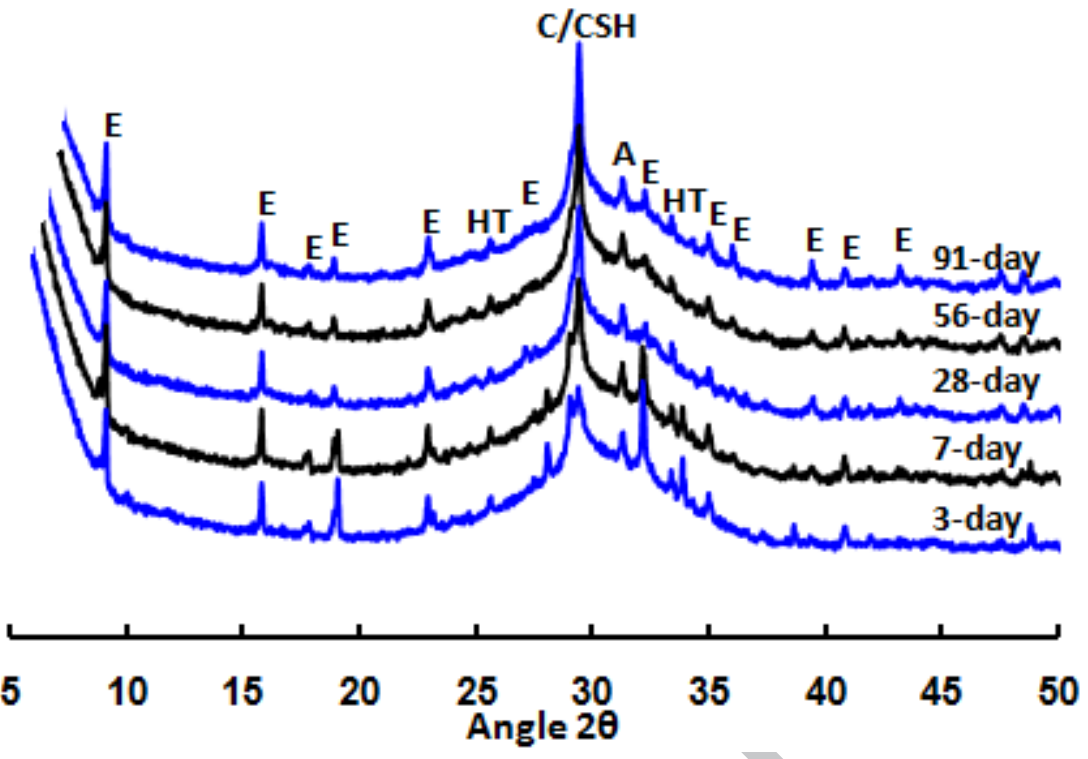

Key: E - ettringite $\mathrm{Ca}_{6} \mathrm{Al}_{2}\left(\mathrm{SO}_{4}\right)_{3}(\mathrm{OH})_{12} .26 \mathrm{H}_{2} \mathrm{O}, \mathrm{HT}$ - hydrotalcite $\mathrm{Mg}_{6} \mathrm{Al}_{2} \mathrm{CO}_{3}$ $(\mathrm{OH})_{16} .4 \mathrm{H}_{2} \mathrm{O}, \mathrm{C} / \mathrm{CSH}$ - overlapping calcite and calcium silicate hydrate, $\mathrm{A}$ akermanite $\mathrm{Ca}_{2} \mathrm{Mg}\left(\mathrm{Si}_{2} \mathrm{O}_{7}\right)$

Fig.9 X-ray patterns of M4 pastes at different ages 


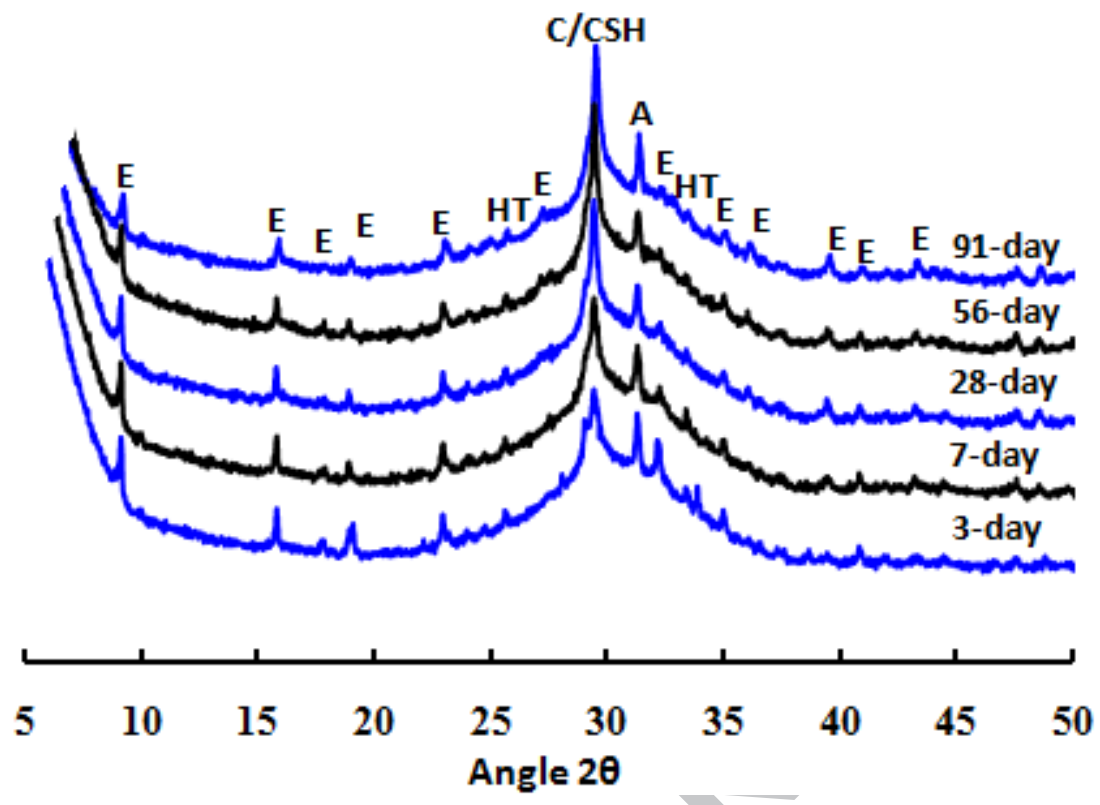

Key: $\mathrm{E}$ - ettringite $\mathrm{Ca}_{6} \mathrm{Al}_{2}\left(\mathrm{SO}_{4}\right)_{3}(\mathrm{OH})_{12} .26 \mathrm{H}_{2} \mathrm{O}$, $\mathrm{HT}$ - hydrotalcite $\mathrm{Mg}_{6} \mathrm{Al}_{2} \mathrm{CO}_{3}$

$(\mathrm{OH})_{16} .4 \mathrm{H}_{2} \mathrm{O}, \mathrm{C} / \mathrm{CSH}$ - overlapping calcite and calcium silicate hydrate, $\mathrm{A}$ akermanite $\mathrm{Ca}_{2} \mathrm{Mg}\left(\mathrm{Si}_{2} \mathrm{O}_{7}\right)$

Fig.10 X-ray patterns of M5 pastes at different ages 


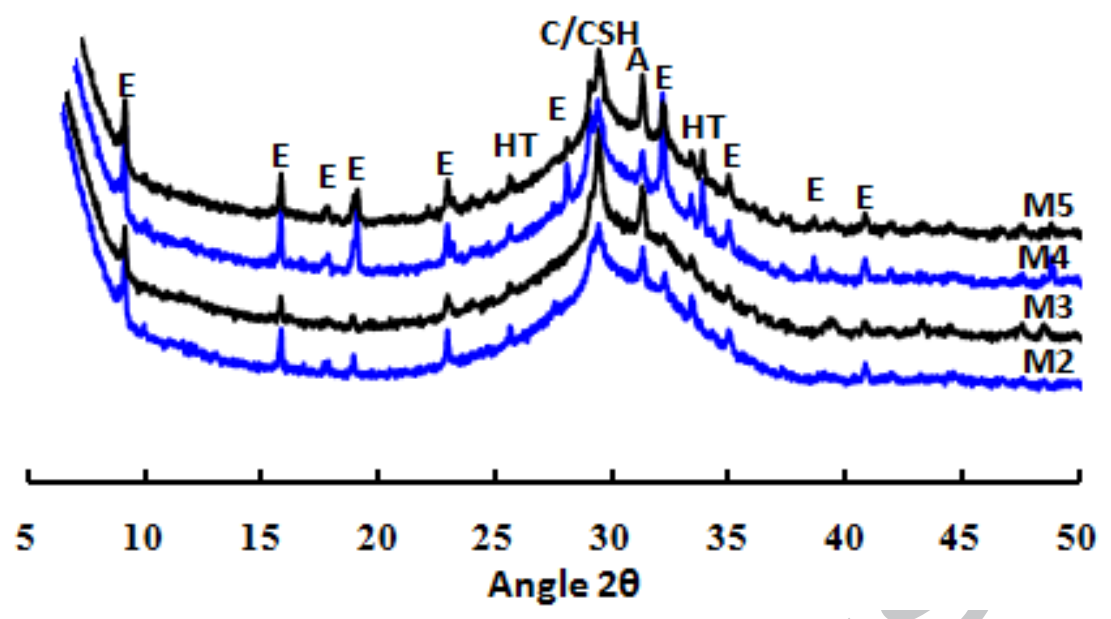

Fig. $11 \mathrm{X}$-ray patterns of hardened activated slag pastes at age of 3 days 


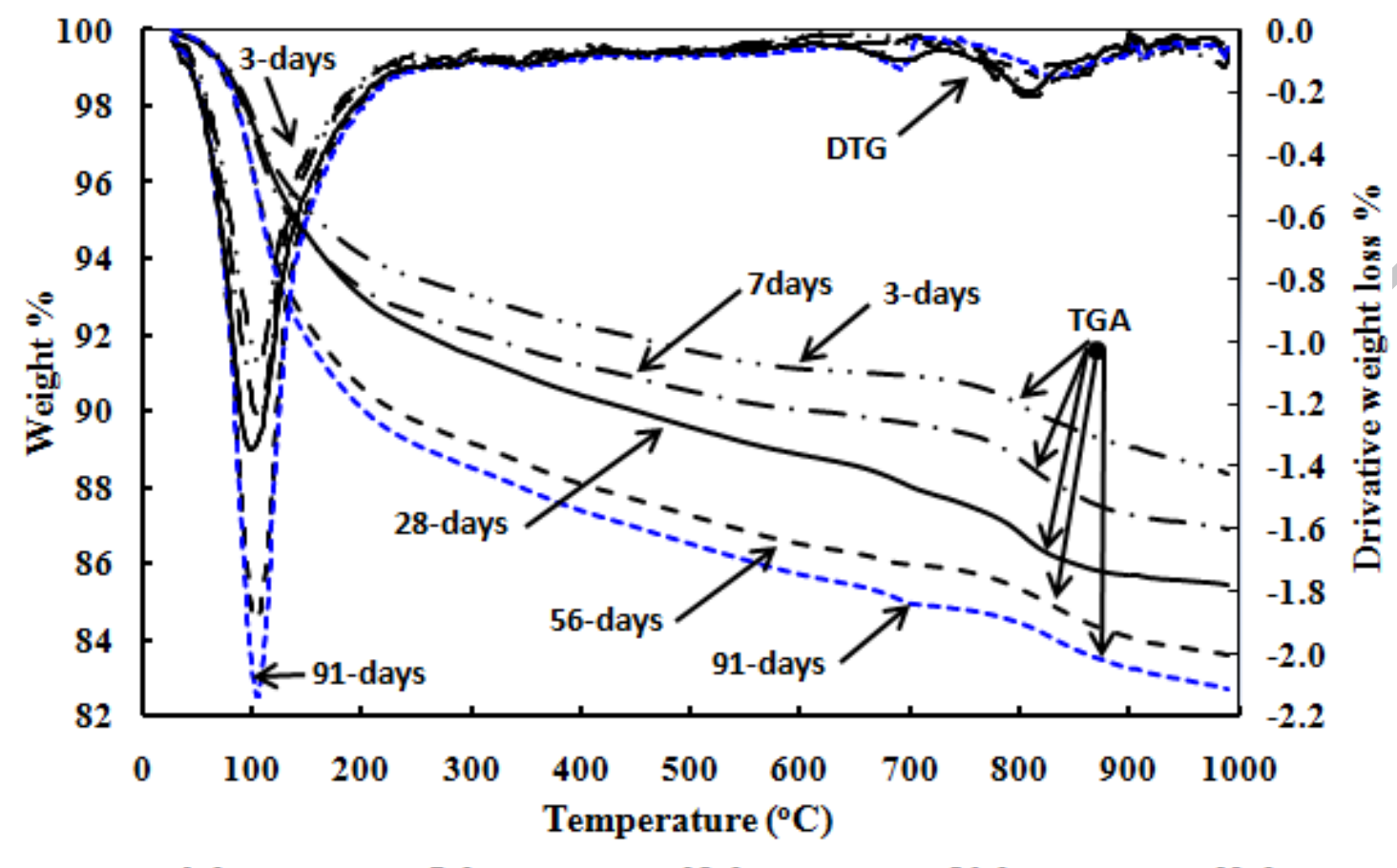

Fig 12 Thermo-gravimetric (TGA) and derivative thermogravimetric (DTG) curves for coarse sample M5 at all ages 


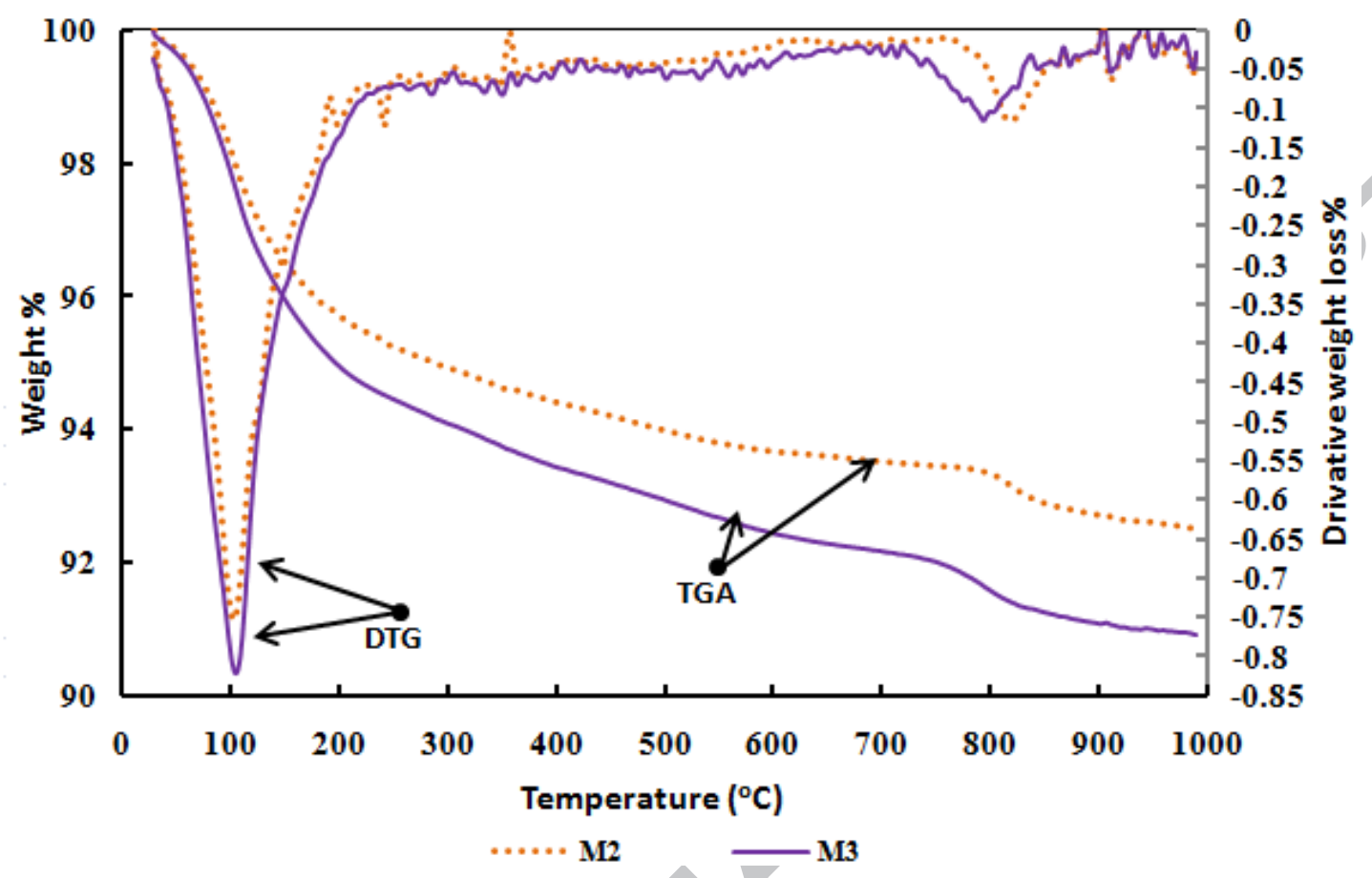

Fig 13 Thermo-gravimetric (TGA) and derivative thermogravimetric (DTG) curves for sample M2 and M3 at age of 3 days 


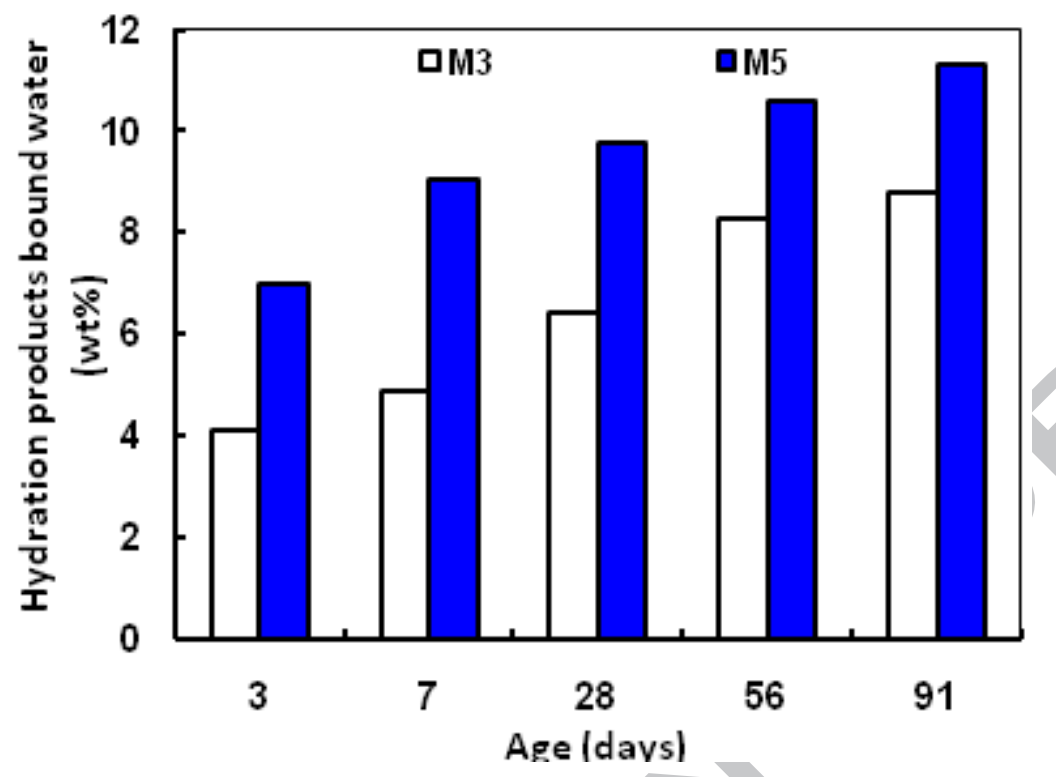

Fig 14 Bound water in hydration products for samples of M3 and M5 


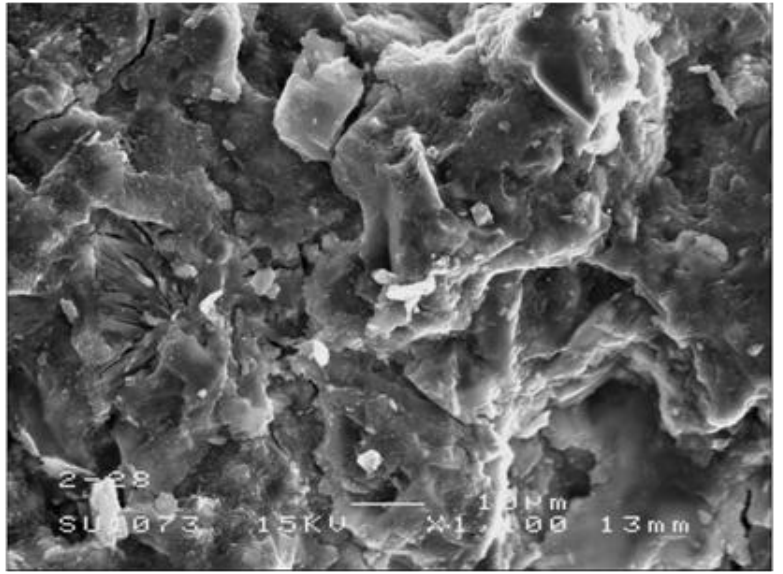

(a) Sample M2

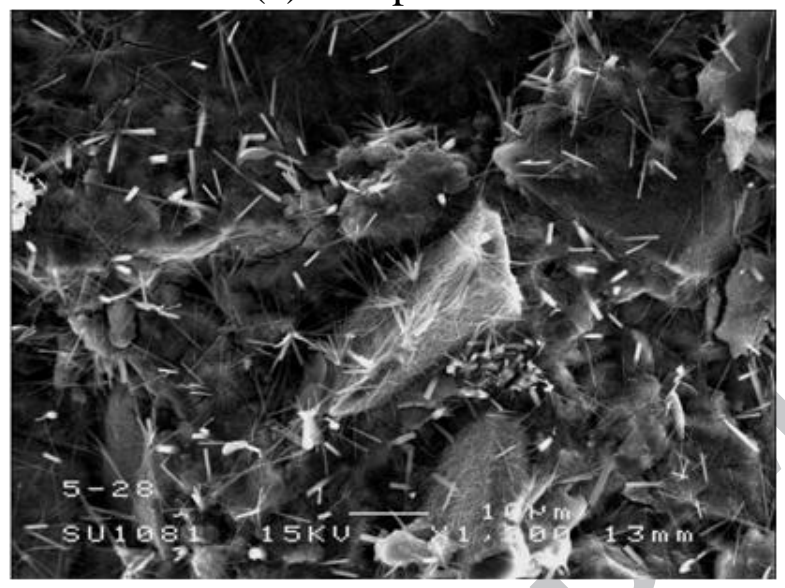

(c) sample M4

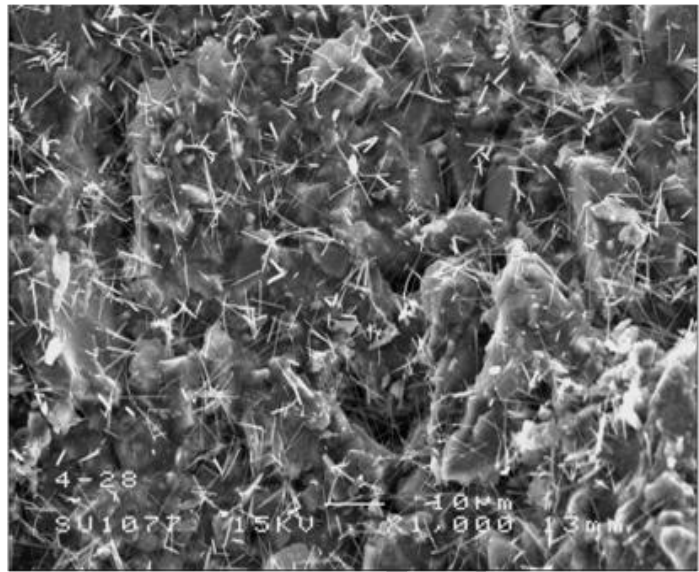

(b) Sample M3

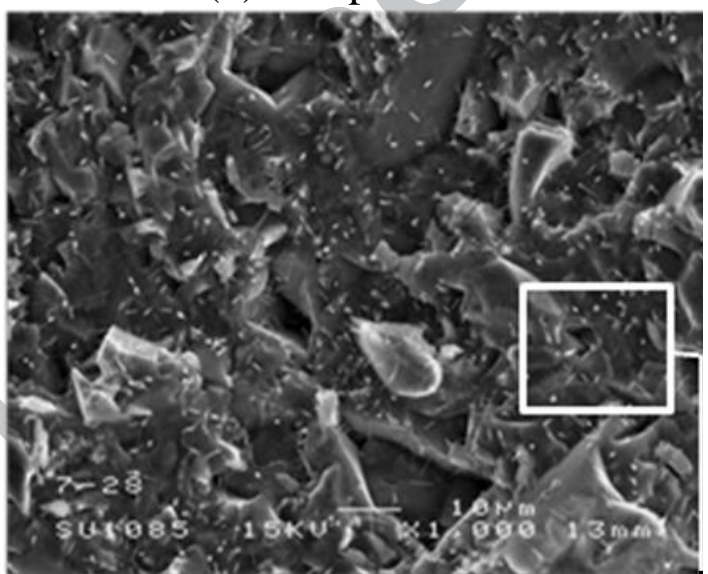

(d) Sample M5

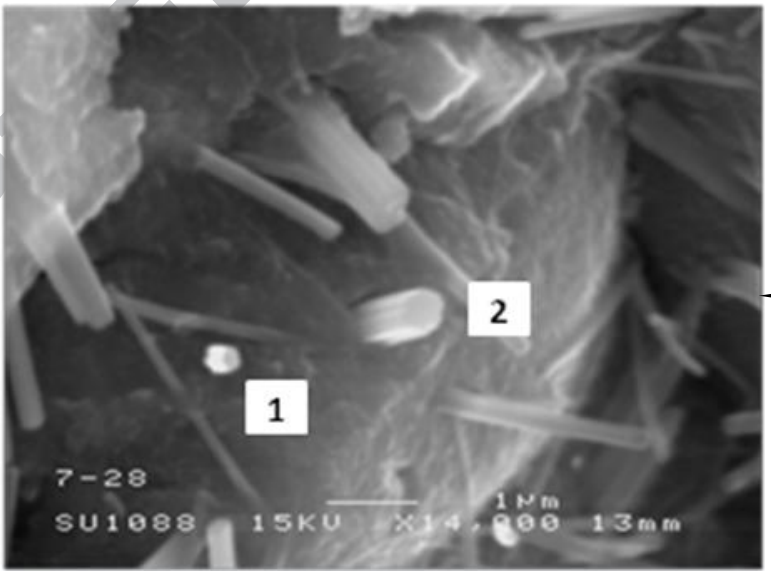

(e)

Fig 15 SEM micrographs of fracture surface of hardened activated slag pastes cured for 28 days 


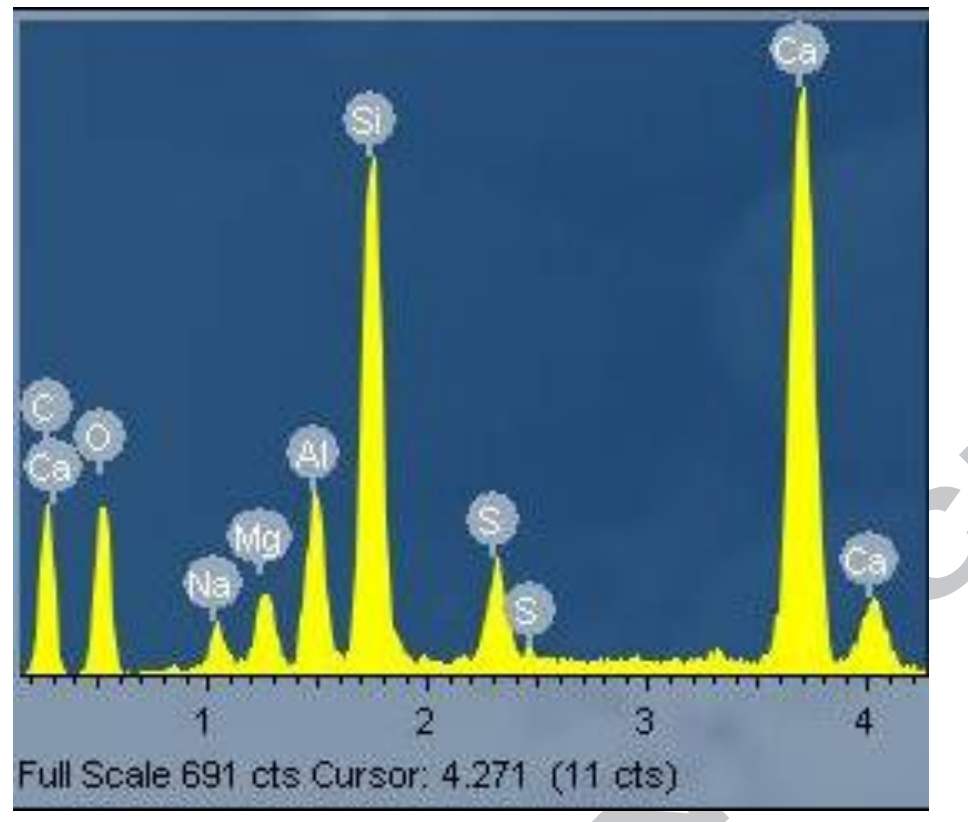

(a)

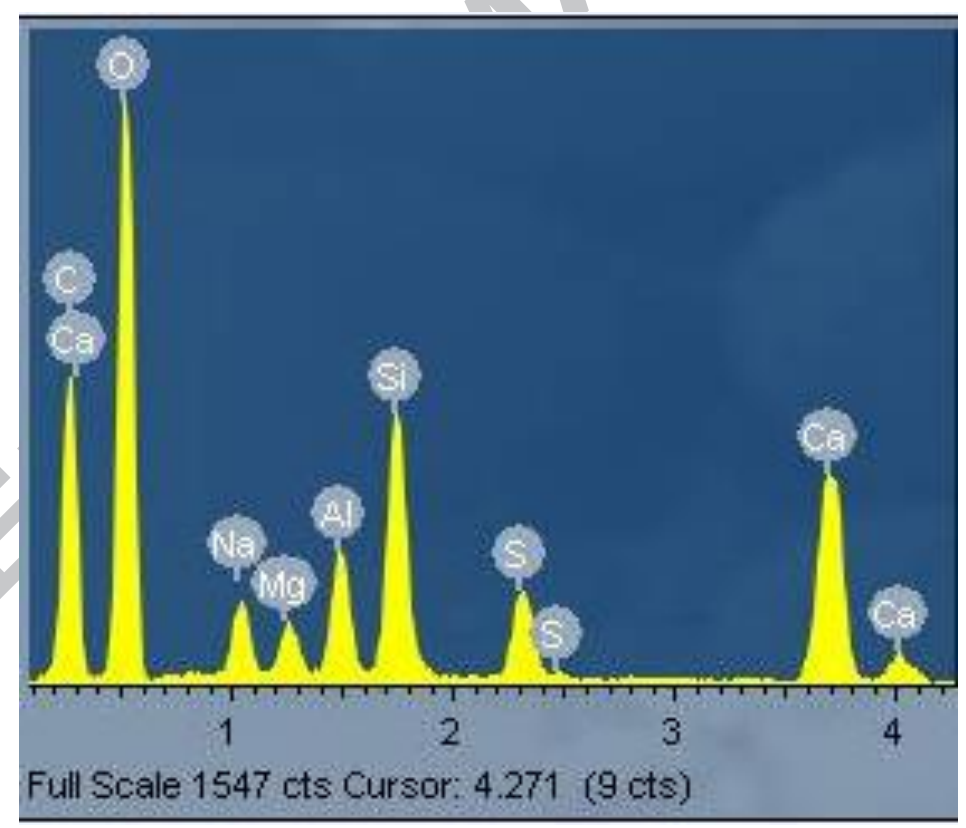

(b)

Fig 16 EDS images for the regions in Fig 15 (e) labeled 1 (a); and 2 (b) 
Table 1 Oxide composition of PC and slag (\% by mass) after calculation

\begin{tabular}{|c|c|c|}
\hline Composition & PC & slag \\
\hline $\mathrm{CaO}$ & 63.47 & 40.89 \\
\hline $\mathrm{SiO}_{2}$ & 20.18 & 34.94 \\
\hline $\mathrm{Al}_{2} \mathrm{O}_{3}$ & 4.83 & 11.69 \\
\hline $\mathrm{MgO}$ & 2.47 & 7.42 \\
\hline $\mathrm{Fe}_{2} \mathrm{O}_{3}$ & 3.16 & 3.32 \\
\hline $\mathrm{SO}_{3}$ & 3.26 & 1.19 \\
\hline $\mathrm{K}_{2} \mathrm{O}$ & 0.52 & 0.34 \\
\hline $\mathrm{Na}_{2} \mathrm{O}$ & 0.16 & 0.16 \\
\hline $\mathrm{TiO}_{2}$ & 0.3 & 0.49 \\
\hline $\mathrm{MnO}$ & 0.22 & 0.27 \\
\hline $\mathrm{P}_{2} \mathrm{O}_{5}$ & 0.09 & 0.01 \\
\hline Loss of ignition & 2.18 & -0.93 \\
\hline Total & 100.34 & 100.71 \\
\hline
\end{tabular}


Table 2 Details of mix proportions

\begin{tabular}{|c|c|}
\hline Mixture & Composition \\
\hline M1 & PC \\
\hline M2 & slag, fineness $2500 \mathrm{~cm}^{2} / \mathrm{g}+1 \%\left(\mathrm{Na}_{2} \mathrm{O}\right.$ equivalent $) \mathrm{Na}_{2} \mathrm{SO}_{4}$ \\
\hline M3 & slag, fineness $5000 \mathrm{~cm}^{2} / \mathrm{g}+1 \%\left(\mathrm{Na}_{2} \mathrm{O}\right.$ equivalent) $\mathrm{Na}_{2} \mathrm{SO}_{4}$ \\
\hline M4 & slag, fineness $2500 \mathrm{~cm}^{2} / \mathrm{g}+3 \%\left(\mathrm{Na}_{2} \mathrm{O}\right.$ equivalent $) \mathrm{Na}_{2} \mathrm{SO}_{4}$ \\
\hline M5 & slag, fineness $5000 \mathrm{~cm}^{2} / \mathrm{g}+3 \%\left(\mathrm{Na}_{2} \mathrm{O}\right.$ equivalent) $\mathrm{Na}_{2} \mathrm{SO}_{4}$ \\
\hline
\end{tabular}


Table $3 \mathrm{pH}$ value of different pastes at different ages

\begin{tabular}{|c|c|c|c|c|c|}
\hline Mix/age & 3-days & 7-days & 28-days & 56-days & 91-days \\
\hline M1 & 12.78 & 12.77 & 12.74 & 12.74 & 12.80 \\
\hline M2 & 12.32 & 12.27 & 12.18 & 12.21 & 12.18 \\
\hline M3 & 12.35 & 12.30 & 12.17 & 12.30 & 12.32 \\
\hline M4 & 12.44 & 12.41 & 12.34 & 12.43 & 12.42 \\
\hline M5 & 12.49 & 12.49 & 12.32 & 12.39 & 12.40 \\
\hline
\end{tabular}

